\title{
Software development and innovation: Exploring the software shift in innovation in Swedish firms
}

\author{
Martin Andersson ${ }^{\text {a,c, }}$, Anna Kusetogullari ${ }^{\mathrm{b}}$, Joakim Wernberg ${ }^{\mathrm{c}}$ \\ ${ }^{a}$ Department of Industrial Economics, Blekinge Institute of Technology (BTH), Karlskrona; Lund University, the Swedish Entrepreneurship Forum, Stockholm, and the \\ Research Institute of Industrial Economics (IFN), Stockholm, Sweden \\ ${ }^{\mathrm{b}}$ Department of Industrial Economics, Blekinge Institute of Technology (BTH), Sweden \\ ${ }^{\mathrm{c}}$ Swedish Entrepreneurship Forum, Stockholm, Sweden
}

\section{A R T I C L E I N F O}

\section{JEL Codes:}

$\mathrm{O} 15$

O32

O33

$\mathrm{O} 43$

L25

Keywords:

Innovation

Software

Software development

Digitalization

Human capital

Software bias

Digital technology

Absorptive capacity

\begin{abstract}
A B S T R A C T
A number of scholars and industry professionals have claimed that there has been a 'software-biased shift' in the nature and direction of innovation, in that software development is a core part of innovation activities in firms across a wide array of industries. Empirical firm-level evidence of such a shift is still scant. In this paper, we employ new and unique firm-level survey data on the frequency and nature of software development among firms in Sweden, matched with the Community Innovation Survey (CIS). We find robust evidence supporting a software bias in innovation, in that software development is associated with a higher likelihood of introducing innovations, as well as higher innovation sales among firms in both manufacturing and service industries. Furthermore, this positive relationship is stronger for firms that employ in-house software developers than for those that only use external developers, suggesting that there is a hierarchy but possibly also a complementarity between in-house and external software development. We also find support for complementarity between software-based technology and human capital; the estimated marginal effect of software development on innovation is particularly strong for firms that combine in-house software development with a highly educated workforce in both STEM and other disciplines.
\end{abstract}

\section{Introduction}

Digitalization has evolved from being primarily associated with the ICT industry in the early 1990 s to becoming a general purpose technology (GPT) that permeates the entire economy (Bresnahan and Trajtenberg, 1995; McAfee and Brynjolfsson, 2017). This puts digital technologies on par with steam power and electricity, but, unlike these previous GPTs, digitalization affects the flow and use of information rather than energy. This has implications for how the new technology affects innovation in the economy.

\subsection{Software's role in digitalization}

The distinguishing features of GPTs are that they are 'pervasive, improving over time and able to spawn new innovations' (Brynjolfsson and McAfee, 2014, p. 76). This is because there is a common technological core, from which a wide variety of different applications can be developed, diffused and recombined across sectors or markets. There are at least three common denominators to digitalization as a GPT: (i) processing capacity, (ii) large, decentralized networks and (iii) software.

Computational processing capacity sets the conditions for what types of operation computers can perform within a given frame of time and energy. Decentralized digital networks connect people, firms and machines and at the same time generate large amounts of data from network interactions. Software is what makes digital technologies programmable. It is the intangible infrastructure used to leverage and direct the resources associated with processing capacity, networks and data, making it possible to tailor programs and applications to address specific needs. Put differently, software programing is essentially what makes digital technologies GPTs. Because of this, software also plays a central

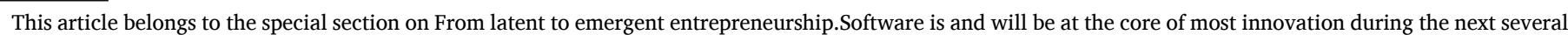
decades (Quinn et al. 1996).

* Corresponding author.

E-mail addresses: martin.andersson@bth.se (M. Andersson), anna.kusetogullari@bth.se (A. Kusetogullari), joakim.wernberg@entreprenorskapsforum.se (J. Wernberg). 
role in how existing businesses use and adapt to using digital technologies to gain productivity benefits.

Software development can, in this sense, be thought of as utilizing an 'ever-expanding set of lego bricks' (Branstetter et al., 2019, p. 543). It enables changes in the conceptual structure of products, services and business models across different industrial sectors and contexts (Porter and Heppelmann, 2015; Svahn et al., 2017). It also facilitates the development of new forms of emergent entrepreneurship and innovation (Caiazza et al., 2020, 2015; Belitski et al. 2019). Because the applications of digital technologies developed in one sector can spread to other parts of the economy and be recombined with other applications of the same technology, digitalization holds considerable potential for new applications and innovation.

\subsection{Research literature on software and innovation}

There is a growing body of empirical evidence suggesting a 'software-biased shift' in the nature and direction of innovation over recent decades (Branstetter et al., 2019), i.e., that new innovations are becoming increasingly software-centered or software-dependent. While this shift toward software-intensive innovation started in industries such as electronics, semiconductors and IT hardware in the 1980s (Arora et al., 2013), it appears to have grown outside of the traditional ICT industry during the 2000s. Many firms in manufacturing and services develop software to differentiate their products and services, as well as to increase user value. ${ }^{1}$ Software development has thus become increasingly integrated into firms' innovation activities.

While this shift toward software-intensive innovation may seem intuitive, there is still little empirical evidence as to its extent and variation across the economy. There are three main lines of research addressing the link between software development and innovation: (i) one studying the growth in software patents and its relationship to firm performance, (ii) one investigating software-intensity or software-dependence in innovation by looking at citations of software patents, and (iii) one focusing on the direct use of software in the innovation process.

Two of these research strands build predominantly on patenting data. The first approach attempts to link software patents to firms' performance. Software patenting captures software development activity as it refers to the intellectual property protection of new and unique intangible assets in the form of, e.g., a computer program, user interface or algorithm. A general finding in this literature is that software patenting tends to be associated with higher market value (Hall and MacGarvie, 2010; Chung et al., 2019). Firms with a larger share of software patents in their patenting activities are also shown to be in a better position to differentiate their products and in this way 'escape' competitive pressure in their respective product markets (Kim et al., 2019).

In the second approach, patenting data are used to study the software-intensity of patent citations, also including nonsoftware patents that cite software patents. Branstetter et al. (2019) find that increased software-intensity is positively associated with research and development (R\&D) productivity (patent output per dollar invested in $R \& D)$ across a range of manufacturing firms in different countries and software-intensive firms also appear to receive considerably higher valuation in equity markets. ${ }^{2}$ Although these studies do not measure

\footnotetext{
1 The argument of a software bias in innovation is also broadly in line with Haskel and Westlake's (2018) argument of the rising role of intangible assets in innovation and productivity growth. They emphasize that software is a key intangible asset that is imperative for explaining innovation and the performance of firms in many different types of industries.

2 In addition, the authors find that the share of software patents among the observed firms increased fourfold, that citations pertaining to software patents increased threefold during the period, and that software-patents are $24 \%$ more likely to be cited than nonsoftware patents even after controlling for the growing number of software patents.
}

innovation outcome directly, they do show that firms that are more deeply engaged in software development and related technologies in their inventive activities perform better than other firms.

Another line of research studies innovation outcome explicitly and analyzes the relationship between innovation and the adoption and use of various types of software. ${ }^{3}$ Engelstätter (2012) estimates the respective influence of enterprise resource planning (ERP), supply chain management (SCM) and customer relationship management (CRM) systems on product and process innovation among a sample of firms in Germany. The study finds that the use of such types of software systems is associated with a higher likelihood of introducing product and process innovations. Another study in the same vein is Niebel et al. (2019), who employ firm-level data for Germany to assess how the use of 'big data analytics' influences both the probability of introducing product innovations and the sales attributed to product innovations. They find a positive influence of the use of big data analytics on innovation and argue that this is consistent with the idea that big data provides firms with new information and decision support, which puts them in a better position to innovate. Several authors also argue that software-based tools, such as simulation and prototyping programs, contribute in different ways to reshaping the innovation process within firms in different parts of the economy (Quinn et al., 1996; Nambisan et al., 2017; Kim et al., 2019; Yoo et al., 2010).

While these types of analysis establish a link between use of enterprise software systems and innovation outcomes, they are more loosely connected to the idea of a software-biased shift in innovation as the adoption or use of such systems does not necessarily imply that firms develop software to refine or develop new products or services. In fact, they may capture the adoption of generic 'off the shelf' enterprise software systems. Engelstätter and Sarbu (2013) also find that, among knowledge-intensive service firms in Germany, the adoption of more generic (sector-specific) software has no relationship to innovation, whereas the adoption of firm-specific software, i.e., software that is customized for a specific firm, does appear to influence firm-level innovation.

\subsection{Contribution and summary of main findings}

This paper contributes to the existing literature with a firm-level analysis of the relationship between software development and innovation outcomes across the Swedish economy. We employ new and unique firm-level survey data on the frequency and nature of software development in Swedish firms, which allow us to assess the relationship between innovation outcomes and software development while controlling for several confounding factors. The main hypothesis underlying the empirical analysis is that, if there is a software-biased shift in firms' innovation activities, then firms engaged in software development should indeed be more likely than other firms to develop new innovations.

In contrast to previous studies, our survey-based data capture software development in firms active in both manufacturing and services and are not contingent on a specific type of secondary indicator, like the adoption of an enterprise software system. Capturing software development in this way is warranted for several reasons. For instance, software development activity is not part of the regular firm-level statistics of firms. Available measures of intangible assets, or investments in such assets, typically do not separate software from other types of intangibles, such as brands, goodwill and other intellectual assets (Haskel and Westlake, 2018). Data on ICT investments include software development, but this is oftentimes bundled with the acquisition of equipment

\footnotetext{
3 There is also a literature that focuses on the link between innovation and various types of ICT more generally (see, e.g., Spiezia, 2011; Brynjolfsson and Saunders, 2009; Kleis et al., 2012; Mohnen et al. 2018), as well as the link between ICT and industries' productivity growth (Edquist and Henrekson, 2017a, 2017b). We focus here on the subset of papers that has a specific focus on software and software development.
} 
and expenditures on 'off the shelf' software. When presented in this manner, it is hard to distinguish software development from lower-order indicators of digital technology like buying computers. ${ }^{4}$

The firm-level survey of software development also allows us to track software development in firms that are not involved in software patenting. ${ }^{5}$ The data include a large-scale sample of 4,598 firms that took part in a survey of software development during 2019. The survey questions cover, among other things, whether the firm developed software, as well as whether the software they developed is developed 'inhouse' by its own personnel or through the use of external service providers, such as software development service firms. In the empirical analysis, we consistently separate firms with in-house software development from firms with only external software development as they represent different degrees to which software development is integrated in firms' business operations.

The firm-level survey data on software development have been matched with the latest Community Innovation Survey (CIS 2018), which allows us to develop established measures of innovation outcomes in the form of the introduction of new products, as well as sales attributed to innovation. They have also been matched with regular firm-level statistics including information on number of employees, industry of operations, ownership structure and international operations. Like Niebel et al. (2019), we estimate two types of models. First, we analyze probit models to assess whether the propensity to introduce product innovations (new goods or services) is larger for firms that develop software. Second, we estimate a fractional response model (Papke and Wooldridge, 1996) to assess the link between innovation sales (defined as the proportion of sales attributed to product innovations) and software development.

We find evidence in favor of the hypothesis of a software bias in innovation across firms in both manufacturing and service industries in the sense that software development is strongly linked to the propensity to introduce innovations, as well as innovation sales. Even after controlling for R\&D investments, human capital, international sales, size, industry and several other typical determinants of firms' propensity to introduce product innovation, we find that the subset of firms that develop software are more likely to introduce product innovations. These findings also hold when analyzing innovation sales, as well as when we run separate models for manufacturing and service firms and for firms of different sizes. Furthermore, the link between software development and innovation is strongest for the firms that develop software in-house. In fact, the conditional marginal effect between innovation sales and software development is primarily statistically significant for firms that develop software in-house. Additional estimations for subsets of firms with different human capital intensities point to the role of absorptive capacity and complementarity between technology and human capital. The link between software development and innovation is particularly strong for firms that combine software development with strong in-house human capital in both STEM (science, technology, engineering and mathematics) and other, 'softer'

\footnotetext{
4 The OECD defines ICT investments as follows: 'the acquisition of equipment and computer software that is used in production for more than one year. ICT has three components: information technology equipment (computers and related hardware); communications equipment; and software. Software includes acquisition of pre-packaged software, customised software and software developed in-house.' See: https://data.oecd.org/ict/ict-investment.htm

5 Studies of software patents show that there is significant heterogeneity among firms and industries in terms of software patenting. Empirical studies point to it primarily being large firms in manufacturing industries with a tradition of accumulating large patent portfolios and of pursuing patents for strategic reasons that develop software patents (Bessen and Hunt, 2007). Using software patenting to measure software development thus runs the risk of introducing a bias toward large manufacturing firms in specific industries. Furthermore, although software patenting is common in countries like the US and China, software patents are not as common in many European countries.
}

disciplines, such as the social sciences. Our analyses provide new empirical evidence on the software bias in innovation in firms by showing that software development, in particular in-house software development, is associated with both a higher likelihood of introducing innovations and higher innovation sales.

\section{Three hypotheses about software development and innovation}

\subsection{Software development and innovation}

How can software development improve or promote innovation? Firms in different industries have used software for many years to improve their operations, including innovation activities. More than 20 years ago, Quinn et al. (1996) claimed that software is a key element in the whole innovation process from basic research to innovation. Their argument was that firms can cut and change several steps in the innovation process and thus make it faster and more efficient by using software. For example, the use of digital CAD/CAM software allows manufacturing firms to simulate the performance of different designs and thereby eliminate many so-called 'build and bust' tests. A similar situation applies to firms in chemicals and biotechnology, as firms in these areas can design and assess new molecules by using various types of software before actually constructing or building new chemical structures. Another example is the use of software in products and services to allow customers to modify products and services to their specific needs, thereby enhancing consumer value while at the same time providing the firms developing such products with better feedback on user needs.

While most of Quinn et al.'s (1996) arguments center on the use of software in various parts of the innovation processes, research on a software-biased shift in innovation suggests that new innovations are also becoming increasingly software-intensive or software-dependent in firms ranging from finance to manufacturing and services. That is, firms not only use software as a tool in innovation activities but increasingly develop software as part of their innovation activities or develop new innovations that incorporate or rely on existing software patents.

What this essentially entails is that even firms that do not explicitly sell software products use software to improve their products and services, to make their internal processes and logistics more efficient or even to reshape their business model. This shift includes emerging cloud service providers but also restaurant chains. For example, the pizza company Domino's uses digital technologies and analytics to improve consumer experience and thus gain a competitive advantage.

The same logic applies to manufacturing firms. Most manufactured products today contain embedded software systems that improve the performance of the hardware product. Ebert and Jones (2009) cite data suggesting that more than 10 years ago (in 2008) there were in the order of 30 embedded microprocessors in products in developed countries and at least 2.5 million function points of embedded software. One example is the automotive industry, in which embedded software combined with electronics hardware is crucial. Embedded software opens up significant opportunities to improve and differentiate vehicles, e.g., in terms of safety enhancements, infotainment, navigation and other types of comfort improvements for passengers (Sedgwick, 2015; Grimm, 2003; Voget, 2003).

The role of software in manufacturing innovation is further illustrated by the large share of R\&D employees in large manufacturingbased multinational firms working with software development. In a survey of the 39 largest R\&D firms in Sweden (including multinational firms like Ericsson, Volvo Cars, SAAB, Scania, ABB, Sandvik, GKN Aero and Electrolux) conducted in 2016, firms reported that four out of 10 R\&D employees are involved in software development. ${ }^{6}$

\footnotetext{
6 https://www.nyteknik.se/innovation/4-av-10-fou-anstallda-utvecklar-pr ogramvara-6578226
} 
Terms like 'Industry 4.0,' 'Industrial Internet of Things (IIoT)' and 'smart manufacturing' are sometimes used to describe the transformation of manufacturing in the wake of digitalization. ${ }^{7}$ A key component in this development is the embeddedness of sensors in devices, machines and products that measure and track performance and generate data in real time (Ezell et al., 2018). This creates a new layer or infrastructure that firms can exploit in their innovation efforts by developing software to generate and analyze data, and to design new and improved services, products and processes. Here, software programming is a tool that can be leveraged to design data-driven products and services, adapt product attributes, improve user services and develop new business models. It can also be used for process innovations like improved management and control systems, logistics and improved overall real-time intelligence about production and logistics processes. Product, process and system innovations in manufacturing industries therefore all often involve significant efforts in software development.

Moreover, in the last 10-15 years a number of new types of firm have entered that exploit digital platforms to develop new business models that 'disrupt' established markets, while also developing new types of markets. Examples of such firms include the 'giant' digital firms like Alibaba, Facebook, Google, Amazon, Airbnb and Uber. In 2011, Marc Andreessen, a software developer who built one of the first widely adopted web browsers and co-founded Netscape, coined the phrase 'Software is eating the world' to describe how software-based business models were outcompeting traditional businesses. ${ }^{8}$ The argument he makes, using the rise of Amazon as an example, is that software-based online business models are able to leverage global networks of customers and at the same time provide an unprecedented variation in supply that is easily searchable, as compared to a physical bookshop with limited supply and geographical constraints on customer reach. These multisided platform economies have been described as 'matchmaking' businesses (Evans and Schmalensee, 2016). Software-based innovations and business models are a core part of the innovations that these types of firms bring to the market. Following a similar logic, emerging digital healthcare providers and edtech companies strive to provide software-based platforms and matching services for healthcare and education.

Taken together, the overview above suggests that software development and software infrastructure provide opportunities that are becoming increasingly important to the competitiveness of firms across the economy (Iansiti and Lakhani, 2014). Software development and digitalization are frequently claimed to open up opportunities for new services, products and business models, as well as new ways to improve operational efficiency, and to bring considerable potential for combinatorial innovation (Schwab, 2017; Raman and Wagner, 2011). Against this backdrop, we formulate the following hypothesis:

H1a: There is a positive relationship between software development and innovation in firms.

Furthermore, the arguments that digitalization and software could be described as GPTs suggest that software should matter for innovation in a wide range of sectors and among types of firms. We therefore expect that the positive relationship between software development and innovation holds for both manufacturing and service industries and for firms of different sizes:

\footnotetext{
7 This development is driven by the adoption, maturity and price reduction of several different technologies like computer-aided design (CAD) and engineering (CAE) software, cloud computing, Internet of Things, advanced sensor technologies, 3D printing and industrial robotics, as well as data analytics, machine learning and wireless connectivity.

8 https://www.wsj.com/articles/SB10001424053111903480904576512250 915629460
}

H1b: There is a positive relationship between software development and innovation in firms on an economy-wide scale (including both manufacturing and service industries, as well as among small and large firms).

While previous studies have narrowed in on specific sectors to find a positive relationship between software development and innovation, it is not evident that such a relationship holds across different sectors and firms, making it a relevant line of further inquiry. Previous studies indicate considerable heterogeneity both in terms of software use within businesses and in the practice of software development (Andersson et al., 2020). For example, some firms may develop software aimed at support activities, while others may develop software that affects the core of their business model. Because digitalization, including software, is a GPT, it has many different uses in different parts of the economy. The question at the heart of H1a and H1b is whether software exhibits a positive relationship with innovation that holds across different parts of the economy.

\subsection{Differences between in-house and external software development}

Firms that develop their own software may do so either by hiring their own developers or by contracting external developers. Some firms may only require software development skills temporarily or for small amounts of recurring work, while others may contract consultants to do development work that could easily have justified hiring an in-house developer. Thus, while all firms that develop software have arguably reached some common basic level in their digital transformation, it may prove hard to make more precise deductions about how far they have come in leveraging digital technologies.

However, firms that hire their own developers are on average more invested in leveraging digital technologies than those that do not. ${ }^{9}$ First of all, the amount a firm spends to internalize software development skills translates into a lot of consulting hours. This is especially true in the Swedish labor market, where taxes on income are considerably higher than the corresponding value added to services. Furthermore, in-house developers contribute continuously to the absorptive capacity (Cohen and Levinthal, 1990) of the firm through their own skills and their interactions with coworkers. External developers, especially who that are contracted for longer periods of time, may also become part of the working environment, but never more so and oftentimes less than employees.

Against this backdrop, we argue that firms using in-house software developers will, on average, be more advanced in their use of digital technologies and thus software development in these firms will also be more deeply integrated into their business operations. Empirically, we test this by comparing firms that use external and in-house developers, respectively. Firms that engage in both in-house and external software development are grouped with those using in-house developers since, by our assumption, this is the more significant indicator of the firm's overall digital transformation. If this is the case, and if there is a positive relationship between software development and innovation, then we should expect a difference between firms employing in-house developers and those using external developers only. This leads us to the second hypothesis:

H2: The effect of in-house software development activity on innovation is greater than the effect of external software development on innovation.

\subsection{Complementary human capital and absorptive capacity}

Successful innovation that involves software development is likely to

\footnotetext{
${ }^{9}$ In our empirical analysis, we separate firms that have in-house developers (whether or not they also use external developers) from those that only use external developers.
} 
need complementary human capital in order to design products and services in ways that appeal to customers, and to also adapt organizational practices and routines to leverage the full potential of digital technology. This brings us to the role of complementary human capital and absorptive capacity.

Established literature in innovation studies suggests that absorptive capacity plays a key role in leveraging the potentials of new technology (Cohen and Levinthal, 1990; Cockburn and Henderson, 1998; Arora and Gambardella, 1994). For example, exploiting the benefits of software requires software capabilities, and characteristics of organizations and routines may not be adapted in ways that make it possible to reap the gains from software. Brynjolfsson and Hitt (2000) make the case that, as computers became cheaper and more powerful, the limit to their business value is not technical but organizational. A historical example is the adoption of the electrical motor, where established firms with sunk costs in physical capital incompatible with the new technology could not leverage it and were outcompeted by others (McAfee and Brynjolfsson, 2017).

A variety of analyses support the role of human capital and absorptive capacity in the context software and digital technology in general. For example, there is significant evidence that the nature of recent technological change, in particular digitalization and the computerization of many workplaces, has been 'skill-biased' in the sense that it has increased the relative demand for skilled employees (Autor et al., 2003). In other words, the adoption of digital technologies and the increasing use of computers in firms and organizations tend to imply greater demand, as well as higher willingness to pay, for human capital. There is also empirical evidence suggesting that investment in ICT, reorganization of workplaces and investment in new products and services are complementary in the sense that doing all three simultaneously rather than in isolation have strong effects on productivity and on demand for skills (Bresnahan et al., 2002). Similar findings are reported by Hempell (2003), who assesses complementarities between investments in ICT and firm-sponsored training of employees among firms in Germany. Brynjolfsson et al. (2002) also provide several examples of how leveraging the potential gains from digital technologies requires changes in routines and organizational capital. Their analysis also shows that firms with high levels of both computer investments and relevant organizational capital have significantly higher market evaluation and also stronger measured productivity. Moreover, the recent analysis of Niebel et al. (2019) on the relationship between the use of big data analytics and innovation outcome among firms in Germany also finds that this relationship is stronger for firms with higher levels of human capital. They infer from this that it reflects the role of absorptive capacity. Their analysis further illustrates that human capital, as measured by the overall education level of employees, is indeed a relevant way to capture absorptive capacity in firms.

We can thus expect heterogeneity across firms in terms of the link between software development and innovation, related to the extent to which firms have relevant absorptive capacity, as evidenced by human capital. If firms prematurely invest in software development without having the necessary absorptive capacity and complementary skills, then the overall link between software and innovation could in fact be weak. In view of this, we formulate the following hypothesis:

H3: The relationship between software development and innovation is stronger in firms with stronger absorptive capacity, as reflected by the level of human capital of their workforce.

Both $\mathrm{H} 2$ and $\mathrm{H} 3$ rely on the same theoretical foundations pertaining to absorptive capacity, with the difference that, while $\mathrm{H} 2$ tests for the difference between in-house developers and external developers, H3 tests more generally how the relationship is affected by the overall presence of STEM workers.

\section{Data, empirical strategy and descriptives}

\subsection{Data}

The analysis is based on a combination of new and unique firm-level survey data on software development (SWD), which has been combined with CIS data and firm-level register data. The SWD survey took place during 2019 and centered on questions concerning whether or not firms had developed software, whether the software had been developed by inhouse employees or external consultants and what function software development had in the firms' business. ${ }^{10}$ It also included questions related to the firms' own perceptions of the market situation, specifically the degree of competition and whether it was a new or established market segment. The design of survey questions and the population frame were developed in collaboration with SWEDSOFT and Statistics Sweden (SCB), which also conducted the survey and validated the results. ${ }^{11}$

Survey questions were sent out to a random sample of 9425 firms within the population frame in Sweden and 4598 firms submitted their response, a response rate of $49 \%$. The person who responded the SWD survey had to be part of the firm's management board, with a role corresponding to chief technology officer or CEO. The survey was merged with the firm-level Community Innovation Survey (CIS 2018). The number of firms that took part in both surveys was 4321, which means that 1752 firms (27.6\%) were lost from the CIS and 277 firms (4.4\%) were lost from the SWD survey.

The SWD survey was undertaken in 2019 and the CIS 2018 referred to the years 2016-2018. This discrepancy in timing is only a minor issue in our empirical context since we are interested in the overall relationship between software development and innovation outcome in firms, rather than a strict causal analysis. The SWD survey was also designed to identify firms that had software development as a part of their business operations, rather than to assess whether a firm developed software in the particular year that the survey was sent out. Moreover, software development is typically not a one-off event but rather involves continuous development, refinements and testing (Ruparelia, 2010; van der Weerd et al., 2006; Ebert, 2007). However, we recognize that the difference in timing of the surveys is a limitation.

We also draw information on firms in the matched sample (SWD-CIS) from the full population register data. These register data include the Firm and Establishment Dynamics database (FEK), Foreign Trade data and the individual-level data from the Longitudinal Individual Level database (LISA). From these register data sources we obtain information on value added, international trade, ownership structure and composition of employees. All data are accessed through the Microdata Online Access (MONA) service, provided by SCB, and refer to the year 2017. ${ }^{12}$ After merging the SWD-CIS data with the balance sheet data, we arrive at 4082 firms. After removing observations with fewer than 10 employees, we have 3947 firms (135 firms were dropped).

The combination of the different sets of data allows us to develop a dataset with unique and detailed information on software development and innovation activities, as well as a number of background characteristics of the firms, such as firm size, education of employees, industry affiliation, export activity, multinationality and R\&D investments.

\subsection{Empirical models, variables and descriptives}

Our measures of innovation outcome are based on CIS 2018, which followed the Oslo Manual recommendations on measuring the degree of

\footnotetext{
10 The complete set of survey questions is available from the authors upon request.

${ }^{11}$ Information about SWEDSOFT is available here: https://www.swedsoft.se/ en/

12 https://www.scb.se/en/services/guidance-for-researchers-and-universit

ies/mona-a-system-for-delivering-microdata/
} 
innovation in firms (OECD, 2005). First, we rely on information whether the firm has introduced a new or substantially improved a product or service over a three-year time span (2016-2018). Following standard practice in the empirical analysis of innovation, the product innovation dummy is a binary variable, which takes the value 1 if the firm has introduced a product innovation and 0 otherwise (Colombelli et al., 2013; Mairesse and Robin, 2012). The product or service can be new to the market or new to a particular firm.

To estimate the relationship between innovation and software development, we first set up a probit model, with which we estimate the respective influence that in-house and external software development has on the probability that a firm introduces a new product innovation. Formally, this model is given by:

$\operatorname{Pr}\left(I_{i}=1 \mid \mathbf{X}_{i}\right)=\Phi\left(\mathbf{X}_{i}^{\prime} \boldsymbol{\Gamma}\right)$

$\mathbf{X}_{i}^{\prime} \boldsymbol{\Gamma}=\alpha+\beta_{1} S W_{i}^{\text {in-house }}+\beta_{2} S W_{i}^{\text {external }}+\mathbf{Z}_{i}^{\prime} \gamma+\varepsilon_{i}$

where $I_{i}=1$ if firm $i$ introduced a product innovation according to CIS 2018 and 0 otherwise. Our key independent variables are $S W_{i}^{\text {in-house }}$ and $S W_{i}^{\text {external }}$. The former is a dummy variable that is 1 if firm $i$ develops software in-house, such that the firm has employees that develop software, and 0 otherwise. The latter variable is a dummy that is 1 if the firm developed software only through the use of external service providers and 0 otherwise. There are no overlaps between these variables. If a firm has both its own software development employees and use external service providers, it is registered as a firm that has software development in-house. $\mathbf{Z}_{i}$ is a vector of control variables. The model in (1) is based on the assumption that software development is an input in the innovation process, which follows empirical papers that treat ICT investments in a similar way (cf. Hall et al., 2013).

Second, we also investigate the link between software development and innovation sales, which is the share of total sales attributed to a new or improved product. The sales ratio of innovative products or services can be interpreted as a measure of the commercial success of a firm's innovation (Mairesse and Mohnen, 2010).

In empirical models with this type of dependent variables, a typical strategy is to employ a log odds transformation of the fractional dependent variable $P$, such that $P^{*}=\ln [P /(1-P)]$. In this case, $P^{*}$ is assumed to be linearly related to the explanatory variables, and the model is estimated with ordinary least squares (OLS). This transformation yields predictions that lie within the $[0,1]$ interval but, as discussed by Papke and Wooldridge (1996) and Wooldridge (2002, p. 662), it has two basic problems. First, it does not allow $P$ to take the extreme values 0 or 1 . Second, the estimated probability $\mathrm{E}(P \mid X)$ cannot be recovered without additional distributional assumptions. A large proportion of the firms in our sample have innovation sales 0 as many firms had not introduced any innovations, and there are also firms whose entire sales were attributed to innovations. Against this backdrop, we estimate the relationship between innovation sales and software development with a fractional probit model (Papke and Wooldridge, 1996). This model can account for observations for which the fraction is 0 or 1 and is more flexible than an OLS model on log odds transformed variables (Papke and Wooldridge, 1996). It applies a quasi-maximum-likelihood procedure and is estimated with the log likelihood function:

$$
L=I S_{i} \ln \left[\mathrm{E}\left(I S_{i} \mid \mathbf{X}_{i}\right)\right]+\left(1-I S_{i}\right) \ln \left[1-\mathrm{E}\left(I S_{i} \mid \mathbf{X}_{i}\right)\right]
$$

in which the expected (E) innovation sales for a firm $i, I S_{i}$, is assumed to be related to the explanatory factors through a probit function $\Phi($.$) . The$ explanatory variables in this model are the same as in the previous model (1), and the variables of main interest are $S W_{i}^{\text {in-house }}$ and $S W_{i}^{\text {external. }}$.

\subsubsection{Control variables}

In both models, the vector $\mathbf{Z}_{i}$ includes various firm characteristics that are typical in empirical analyses of innovation outcome in firms. To control for the fact that spending on R\&D is a typical driver of innovation, we control for $R \& D$ expenses. Firms that engage in R\&D are better apt to introduce new products and services, and are in a better position to absorb technology and knowledge developed elsewhere (Cohen and Levinthal, 1990), which adds to their innovativeness (Parisi, 2006). We capture $R \& D$ expenses by including total $R \& D$ spending (in-house plus external) divided by total sales. We also account for whether firms are engaged in persistent $R \& D$ or temporary $R \& D$. These data are drawn from the CIS-survey, and the separation matters as firms engaged in persistent $\mathrm{R} \& \mathrm{D}$ are more likely to develop routines and skills with regard to $R \& D$ activities. Empirical research shows that firms undertaking persistent R\&D are more associated with innovative activities (Lööf et al., 2012).

Other control variables include firm size, average employee age, and the education level of firms' employees. An extensive literature emphasizes a relationship between firm size, innovation and technology adoption (Schumpeter, 1942; Cohen, 2010), and whether small or large firms are more technologically innovative has engaged academics for decades. One argument is that small firms are more likely to innovate and account for a large share of innovations (Acs and Audretsch, 1988). Smaller firms might for instance be more flexible and adapt to technological change quicker. At the same time, large firms have greater internal resources and capabilities, and might therefore be more likely to involve in and adopt a wider range of new products and services (Pan and Jang, 2008). Still, they could be subject to issues related to bureaucracy and coordination. To control for the influence of firm size on innovation, we measure firms' size by the logarithm of the number of employees.

The average age of a firm's employees is commonly used determinant of innovation (Schubert and Andersson, 2015; Pfeifer and Wagner, 2014). ${ }^{13}$ A key argument is that older employees may be less motivated to use and adapt to new technologies, while younger employees are more inclined to adopt and adapt to recent technological skills or join firms with greater innovation potential (Ouimet and Zarutskie, 2014). This suggests that firms with a larger share of older employees may have lower innovation propensities and innovation sales. We compute the average age of employees from information on individual employees in the LISA database.

The education level of employees is an established proxy for human capital in firms. We develop two measures of human capital. First, we use data on education to identify employees with a long university education (at least three years). The education of each worker in LISA is coded in accordance with the SUN2000 (Swedish education) nomenclature, which contains information about the level of education. ${ }^{14}$ Second, we consider the type of education that is also available in the SUN2000 nomenclature. We use this information to construct two variables: (i) the proportion of employees in the firm with a long university education in STEM (science, technology, engineering and mathematics) and (ii) the proportion of employees with a long university education in fields other than STEM. ${ }^{15}$ The rationale for these two variables is that firms with highly educated and technically qualified employees are typically claimed to be in better position to develop innovations (Freel, 2003). By having two variables reflecting education in different fields, we are able

\footnotetext{
$\overline{13}$ It should be pointed out that average employee age is associated with the caveat that it may hide variation in age distributions between seemingly similar firms. For this reason, we limit our analysis with respect to age to relating our findings to the existing literature based on the same type of data.

${ }^{14}$ Long university education is defined as employees with any of the following codes: 53 - three years; 54 - four years; 55 - five or longer. Doctorate education: $64-\mathrm{PhD} ; 62$ - licentiate.

${ }^{15}$ Code 4 - Biology and environmental science; physics, chemistry and geoscience; mathematics and natural science; computer science. Code 5 Engineering.
} 
Table 1

Probit regression, dependent variable: dummy for product or service innovation.

\begin{tabular}{|c|c|c|c|c|c|c|}
\hline & $\begin{array}{l}\text { (1) } \\
\text { Full sample }\end{array}$ & $\begin{array}{l}\text { (2) } \\
\text { Manufacturing }\end{array}$ & $\begin{array}{l}\text { (3) } \\
\text { Services }\end{array}$ & $\begin{array}{l}\text { (4) } \\
\text { Small }\end{array}$ & $\begin{array}{l}\text { (5) } \\
\text { Medium }\end{array}$ & $\begin{array}{l}(6) \\
\text { Large }\end{array}$ \\
\hline In-house software development & $\begin{array}{l}0.166^{* * *} \\
(0.020)\end{array}$ & $\begin{array}{l}0.070 * \\
(0.040)\end{array}$ & $\begin{array}{l}0.192^{* * *} \\
(0.023)\end{array}$ & $\begin{array}{l}0.191^{* * *} \\
(0.029)\end{array}$ & $\begin{array}{l}0.136 * * * \\
(0.034)\end{array}$ & $\begin{array}{l}0.117 * * \\
(0.052)\end{array}$ \\
\hline External software development & $\begin{array}{l}0.096^{* * *} \\
(0.023)\end{array}$ & $\begin{array}{l}0.054 \\
(0.040)\end{array}$ & $\begin{array}{l}0.114^{* * *} \\
(0.028)\end{array}$ & $\begin{array}{l}0.095^{* * *} \\
(0.032)\end{array}$ & $\begin{array}{l}0.102^{* * *} \\
(0.039)\end{array}$ & $\begin{array}{l}0.102^{*} \\
(0.059)\end{array}$ \\
\hline Persistent R\&D & $\begin{array}{l}0.306^{* * *} \\
(0.029)\end{array}$ & $\begin{array}{l}0.320 * * * \\
(0.049)\end{array}$ & $\begin{array}{l}0.242^{* * *} \\
(0.039)\end{array}$ & $\begin{array}{l}0.284^{* * *} \\
(0.043)\end{array}$ & $\begin{array}{l}0.287 * * * \\
(0.047)\end{array}$ & $\begin{array}{l}0.293^{* * *} \\
(0.073)\end{array}$ \\
\hline Temporary R\&D & $\begin{array}{l}0.209 * * * \\
(0.064)\end{array}$ & $\begin{array}{l}0.124 \\
(0.089)\end{array}$ & $\begin{array}{l}0.304 * * * \\
(0.092)\end{array}$ & $\begin{array}{l}0.186^{* *} \\
(0.083)\end{array}$ & $\begin{array}{l}0.261^{* *} \\
(0.103)\end{array}$ & $\begin{array}{l}0.250 \\
(0.220)\end{array}$ \\
\hline $\mathrm{R} \& \mathrm{D}$ expenses $(\%)$ & $\begin{array}{l}-0.000 \\
(0.001)\end{array}$ & $\begin{array}{l}2.107^{* *} \\
(0.931)\end{array}$ & $\begin{array}{l}-0.000 \\
(0.000)\end{array}$ & $\begin{array}{l}-0.000 \\
(0.000)\end{array}$ & $\begin{array}{l}0.010 \\
(0.010)\end{array}$ & $\begin{array}{l}4.471 \\
(3.407)\end{array}$ \\
\hline Number of employees (log) & $\begin{array}{l}-0.003 \\
(0.007)\end{array}$ & $\begin{array}{l}0.015 \\
(0.015)\end{array}$ & $\begin{array}{l}-0.008 \\
(0.008)\end{array}$ & $\begin{array}{l}-0.011 \\
(0.021)\end{array}$ & $\begin{array}{l}-0.023 \\
(0.029)\end{array}$ & $\begin{array}{l}0.074 * * \\
(0.029)\end{array}$ \\
\hline Average age of employees & $\begin{array}{l}-0.005^{* * *} \\
(0.001)\end{array}$ & $\begin{array}{l}-0.008^{* * *} \\
(0.003)\end{array}$ & $\begin{array}{l}-0.004^{* * *} \\
(0.001)\end{array}$ & $\begin{array}{l}-0.006^{* * *} \\
(0.002)\end{array}$ & $\begin{array}{l}-0.004 \\
(0.003)\end{array}$ & $\begin{array}{l}0.000 \\
(0.004)\end{array}$ \\
\hline Employees with long university education in STEM (\%) & $\begin{array}{l}0.147^{* * *} \\
(0.054)\end{array}$ & $\begin{array}{l}0.215 \\
(0.173)\end{array}$ & $\begin{array}{l}0.113^{*} \\
(0.058)\end{array}$ & $\begin{array}{l}0.122^{*} \\
(0.066)\end{array}$ & $\begin{array}{l}0.046 \\
(0.108)\end{array}$ & $\begin{array}{l}0.775^{* * *} \\
(0.234)\end{array}$ \\
\hline Employees with long university education, except STEM (\%) & $\begin{array}{l}-0.023 \\
(0.070)\end{array}$ & $\begin{array}{l}0.026 \\
(0.320)\end{array}$ & $\begin{array}{l}-0.016 \\
(0.071)\end{array}$ & $\begin{array}{l}-0.011 \\
(0.083)\end{array}$ & $\begin{array}{l}0.074 \\
(0.140)\end{array}$ & $\begin{array}{l}-0.630^{* *} \\
(0.294)\end{array}$ \\
\hline Exporter & $\begin{array}{l}0.065^{* * *} \\
(0.018)\end{array}$ & $\begin{array}{l}0.047 \\
(0.036)\end{array}$ & $\begin{array}{l}0.074^{* * *} \\
(0.021)\end{array}$ & $\begin{array}{l}0.090 * * * \\
(0.023)\end{array}$ & $\begin{array}{l}0.034 \\
(0.034)\end{array}$ & $\begin{array}{l}-0.012 \\
(0.056)\end{array}$ \\
\hline MNE & $\begin{array}{l}0.036 * * \\
(0.018)\end{array}$ & $\begin{array}{l}0.034 \\
(0.033)\end{array}$ & $\begin{array}{l}0.032 \\
(0.021)\end{array}$ & $\begin{array}{l}0.035 \\
(0.024)\end{array}$ & $\begin{array}{l}0.051 * \\
(0.030)\end{array}$ & $\begin{array}{l}0.023 \\
(0.053)\end{array}$ \\
\hline $\begin{array}{l}\text { New market with high competition } \\
\text { (ref: established market with low competition) }\end{array}$ & $\begin{array}{l}0.075 \\
(0.051)\end{array}$ & $\begin{array}{l}0.031 \\
(0.130)\end{array}$ & $\begin{array}{l}0.080 \\
(0.055)\end{array}$ & $\begin{array}{l}0.025 \\
(0.059)\end{array}$ & $\begin{array}{l}0.277^{* *} \\
(0.122)\end{array}$ & $\begin{array}{l}0.169 \\
(0.219)\end{array}$ \\
\hline $\begin{array}{l}\text { New market with low competition } \\
\text { (ref: established market with low competition) }\end{array}$ & $\begin{array}{l}0.060 \\
(0.053)\end{array}$ & $\begin{array}{l}0.072 \\
(0.122)\end{array}$ & $\begin{array}{l}0.055 \\
(0.059)\end{array}$ & $\begin{array}{l}0.108^{*} \\
(0.058)\end{array}$ & $\begin{array}{l}-0.132 \\
(0.146)\end{array}$ & $\begin{array}{l}0 \\
(0.0)\end{array}$ \\
\hline $\begin{array}{l}\text { Established market with high competition } \\
\text { (ref: established market with low competition) }\end{array}$ & $\begin{array}{l}0.001 \\
(0.020)\end{array}$ & $\begin{array}{l}-0.006 \\
(0.035)\end{array}$ & $\begin{array}{l}0.007 \\
(0.024)\end{array}$ & $\begin{array}{l}-0.003 \\
(0.023)\end{array}$ & $\begin{array}{l}0.036 \\
(0.040)\end{array}$ & $\begin{array}{l}-0.120 \\
(0.077)\end{array}$ \\
\hline $\begin{array}{l}\text { Test of equality of coefficients between in-house and external software development } \\
\left(\mathrm{Chi}^{2}\right)\end{array}$ & $6.34 *(0.01)$ & $0.09(0.76)$ & $5.62 *(0.02)$ & $5.69 *(0.01)$ & $\begin{array}{l}0.56 \\
(0.46)\end{array}$ & $0.06(0.80)$ \\
\hline Industry dummies & YES & YES & YES & YES & YES & YES \\
\hline Pseudo R-squared & 0.120 & 0.143 & 0.111 & 0.111 & 0.116 & 0.263 \\
\hline \# observations & 3930 & 1187 & 2743 & 2346 & 1221 & 361 \\
\hline
\end{tabular}

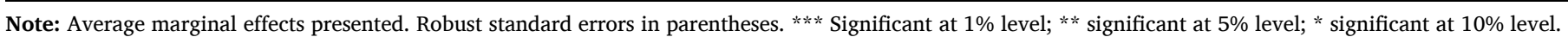

to assess the importance of STEM relative to other educational profiles.

In addition, we control for whether the firm is part of a multinational enterprise ( $M N E)$. Affiliation to an MNE could raise innovativeness because it implies access to knowledge, technology and other internal resources within MNEs, for example through transfers through internal networks from country to country (Cantwell and Iammarino, 2005; Frenz and Ietto-Gillies, 2007). This implies that firms that belong to an MNE are more likely than independent firms to engage in innovation activities. We further include a dummy variable for whether the firm is engaged in exports to foreign markets (Exporter). Firms may use the interaction with foreign customers as a source of ideas and inspirations for a new product (Fassio, 2018; Cassiman and Golovko, 2011; Andersson and Löö, 2009). Moreover, firms exposed to the international market face stronger competition, which suggests that they need to be involved in some product modification and process improvements.

We also control for the degree of competition in the market (both domestic and international) and whether a firm is operating in a new or established market segment. The potential relationship between market competition and innovation has been discussed since at least Schumpeter's distinction between Mark I and Mark II (Schumpeter, 1934, 1942). Mark I considers low technological entry barriers and high market competition as drivers of innovation and small firms. Mark II suggests instead that large firms in established markets with high entry barriers should drive innovation (Malerba and Orsenigo, 1996). Novel innovative products may open prospects for firms to create a new niche market. Moreover, firms operating in a high competition market may be more driven toward innovative activity since they are prone to operating closer to their production frontiers or to stimulate the adoption of new technologies. To capture the degree of competition, we use information in the SWD survey in which firms were asked to classify the nature of competition in their main markets. ${ }^{16}$ Lastly, we account for a structural difference between sectoral environment by including industry dummies constructed from NACE industry codes and looking closer at manufacturing and service firms.

\subsubsection{Descriptives}

Table A.1 in the appendix presents descriptive statistics for all variables used in the empirical analyses and Table A.2 presents differences in means between firms with and without software development, as well as between firms with in-house and external software development. Table A. 3 also presents correlations between the variables in the analysis.

With respect to our innovation variables, we see that $41 \%$ of the firms were innovators and the average share of sales due to new or improved products and services, i.e., innovations, was $9 \%$. Looking at software development, we see that $21 \%$ of the firms in the sample had in-house software development, while $11 \%$ of the firms developed software externally. Accordingly, $32 \%$ of the firms in the sample reported that they engaged in software development in-house or through external service providers.

The sample of firms mainly consisted of small (60\%) and mediumsized (31\%) companies. The average age of employees was about 41 years, with a minimum of 21 years and a maximum of 69 years. The average proportion of employees with a long university education in STEM was $19 \%$, while the proportion of employees with a long

\footnotetext{
${ }^{16}$ Four options were provided: (i) new market with high competition, (ii) new market with low competition, (iii) established market with high competition and (iv) established market with low competition.
} 
Table 2

Fractional probit regression, dependent variable: innovation sales (\%).

\begin{tabular}{|c|c|c|c|c|c|c|}
\hline & $\begin{array}{l}\text { (1) } \\
\text { Full sample }\end{array}$ & $\begin{array}{l}(2) \\
\text { Manufacturing }\end{array}$ & $\begin{array}{l}\text { (3) } \\
\text { Services }\end{array}$ & $\begin{array}{l}(4) \\
\text { Small }\end{array}$ & $\begin{array}{l}(5) \\
\text { Medium }\end{array}$ & $\begin{array}{l}(6) \\
\text { Large }\end{array}$ \\
\hline In-house software development & $\begin{array}{l}0.041^{* * *} \\
(0.007)\end{array}$ & $\begin{array}{l}0.030 * * \\
(0.012)\end{array}$ & $\begin{array}{l}0.043^{* * *} \\
(0.008)\end{array}$ & $\begin{array}{l}0.061^{* * *} \\
(0.010)\end{array}$ & $\begin{array}{l}0.023^{* *} \\
(0.010)\end{array}$ & $\begin{array}{l}-0.017 \\
(0.019)\end{array}$ \\
\hline External software development & $\begin{array}{l}0.019 * * \\
(0.008)\end{array}$ & $\begin{array}{l}0.009 \\
(0.014)\end{array}$ & $\begin{array}{l}0.022^{* *} \\
(0.010)\end{array}$ & $\begin{array}{l}0.026 * * \\
(0.012)\end{array}$ & $\begin{array}{l}0.021^{*} \\
(0.012)\end{array}$ & $\begin{array}{l}-0.035 \\
(0.024)\end{array}$ \\
\hline Persistent R\&D & $\begin{array}{l}0.057 * * * \\
(0.008)\end{array}$ & $\begin{array}{l}0.067^{* * *} \\
(0.012)\end{array}$ & $\begin{array}{l}0.048^{* * *} \\
(0.011)\end{array}$ & $\begin{array}{l}0.055^{* * *} \\
(0.013)\end{array}$ & $\begin{array}{l}0.051^{* * *} \\
(0.010)\end{array}$ & $\begin{array}{l}0.067^{* * *} \\
(0.024)\end{array}$ \\
\hline Temporary RD & $\begin{array}{l}0.033^{*} \\
(0.018)\end{array}$ & $\begin{array}{l}0.025 \\
(0.027)\end{array}$ & $\begin{array}{l}0.048^{* *} \\
(0.024)\end{array}$ & $\begin{array}{l}0.042 \% \\
(0.024)\end{array}$ & $\begin{array}{l}0.024 \\
(0.031)\end{array}$ & $\begin{array}{l}0.052 * \\
(0.030)\end{array}$ \\
\hline R\&D expenses (\%) & $\begin{array}{l}0.000 \\
(0.000)\end{array}$ & $\begin{array}{l}0.101 * * \\
(0.042)\end{array}$ & $\begin{array}{l}0.000 \\
(0.000)\end{array}$ & $\begin{array}{l}0.000 \\
(0.000)\end{array}$ & $\begin{array}{l}0.012^{* * *} \\
(0.003)\end{array}$ & $\begin{array}{l}-0.046 \\
(0.088)\end{array}$ \\
\hline Number of employees (log) & $\begin{array}{l}-0.012^{* * *} \\
(0.003)\end{array}$ & $\begin{array}{l}-0.006 \\
(0.005)\end{array}$ & $\begin{array}{l}-0.014^{* * *} \\
(0.003)\end{array}$ & $\begin{array}{l}-0.026^{* * *} \\
(0.008)\end{array}$ & $\begin{array}{l}-0.005 \\
(0.008)\end{array}$ & $\begin{array}{l}0.008 \\
(0.009)\end{array}$ \\
\hline Average age of employees & $\begin{array}{l}-0.002^{* * *} \\
(0.000)\end{array}$ & $\begin{array}{l}-0.002^{* *} \\
(0.001)\end{array}$ & $\begin{array}{l}-0.002^{* * *} \\
(0.001)\end{array}$ & $\begin{array}{l}-0.003^{* * *} \\
(0.001)\end{array}$ & $\begin{array}{l}-0.002^{* *} \\
(0.001)\end{array}$ & $\begin{array}{l}0.002 \\
(0.001)\end{array}$ \\
\hline Employees with long university education in STEM (\%) & $\begin{array}{l}0.068^{* * *} \\
(0.017)\end{array}$ & $\begin{array}{l}0.139 * * * \\
(0.047)\end{array}$ & $\begin{array}{l}0.049^{* * *} \\
(0.018)\end{array}$ & $\begin{array}{l}0.072^{* * *} \\
(0.021)\end{array}$ & $\begin{array}{l}0.006 \\
(0.027)\end{array}$ & $\begin{array}{l}0.196^{* * *} \\
(0.067)\end{array}$ \\
\hline Employees with long university education, except STEM (\%) & $\begin{array}{l}-0.060^{* * *} \\
(0.022)\end{array}$ & $\begin{array}{l}-0.129 \\
(0.095)\end{array}$ & $\begin{array}{l}-0.052^{* *} \\
(0.022)\end{array}$ & $\begin{array}{l}-0.057^{* *} \\
(0.028)\end{array}$ & $\begin{array}{l}0.006 \\
(0.033)\end{array}$ & $\begin{array}{l}-0.306^{* * *} \\
(0.106)\end{array}$ \\
\hline Exporter & $\begin{array}{l}0.023^{* * *} \\
(0.007)\end{array}$ & $\begin{array}{l}0.006 \\
(0.014)\end{array}$ & $\begin{array}{l}0.027 * * * \\
(0.008)\end{array}$ & $\begin{array}{l}0.021 * * \\
(0.009)\end{array}$ & $\begin{array}{l}0.027 * * \\
(0.011)\end{array}$ & $\begin{array}{l}0.021 \\
(0.027)\end{array}$ \\
\hline MNE & $\begin{array}{l}0.003 \\
(0.006)\end{array}$ & $\begin{array}{l}-0.014 \\
(0.011)\end{array}$ & $\begin{array}{l}0.011 \\
(0.008)\end{array}$ & $\begin{array}{l}-0.002 \\
(0.009)\end{array}$ & $\begin{array}{l}0.012 \\
(0.010)\end{array}$ & $\begin{array}{l}0.017 \\
(0.024)\end{array}$ \\
\hline New market with high competition & $\begin{array}{l}0.028 * * \\
(0.014)\end{array}$ & $\begin{array}{l}-0.011 \\
(0.027)\end{array}$ & $\begin{array}{l}0.032^{* *} \\
(0.016)\end{array}$ & $\begin{array}{l}0.024 \\
(0.017)\end{array}$ & $\begin{array}{l}0.048^{* *} \\
(0.022)\end{array}$ & $\begin{array}{l}0.015 \\
(0.066)\end{array}$ \\
\hline New market with low competition & $\begin{array}{l}0.047^{* * * *} \\
(0.017)\end{array}$ & $\begin{array}{l}0.016 \\
(0.032)\end{array}$ & $\begin{array}{l}0.051^{* *} \\
(0.020)\end{array}$ & $\begin{array}{l}0.050^{* *} \\
(0.020)\end{array}$ & $\begin{array}{l}-0.012 \\
(0.030)\end{array}$ & $\begin{array}{l}-0.665^{* * *} \\
(0.073)\end{array}$ \\
\hline Established market with high competition & $\begin{array}{l}0.005 \\
(0.007)\end{array}$ & $\begin{array}{l}-0.001 \\
(0.012)\end{array}$ & $\begin{array}{l}0.010 \\
(0.009)\end{array}$ & $\begin{array}{l}0.003 \\
(0.009)\end{array}$ & $\begin{array}{l}0.021 * \\
(0.012)\end{array}$ & $\begin{array}{l}-0.041 \\
(0.032)\end{array}$ \\
\hline $\begin{array}{l}\text { Test of equality of coefficients between in-house and external software development } \\
\left(\mathrm{Chi}^{2}\right)\end{array}$ & $6.15 *(0.01)$ & $1.81(0.17)$ & $3.70 *(0.05)$ & $6.68 *(0.01)$ & $0.01(0.91)$ & $0.79(0.38)$ \\
\hline Industry dummies & YES & YES & YES & YES & YES & YES \\
\hline Observations & 3930 & 1187 & 2743 & 2346 & 1221 & 363 \\
\hline
\end{tabular}

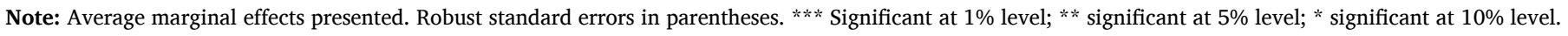

university education in fields other than STEM amounted to $9 \%$. With a share of $77 \%$, considerably more firms perceived the market conditions to be best described as an established market with high competition. Additionally, the majority of firms were in the service sector, while $30 \%$ of firms were manufacturers.

Table A. 2 presents differences in means between (i) firms with external SWD and no SWD, (ii) firms with in-house SWD and no SWD and (iii) firms with in-house SWD and external SWD. What is clear from this table is that the unconditional differences between firms follow a type of hierarchy whereby the proportion of firms that reported innovation is on average highest among firms with in-house SWD, followed by firms with external SWD and finally firms with no SWD. This pattern holds for the innovation dummy as well as innovation sales. It also holds for the indicator of persistent $R \& D$, but there are no significant differences between the groups of firms when it comes to R\&D intensity. This implies that firms that develop software are on average more likely to engage in persistent $R \& D$ activity, although $R \& D$ expenses in relation to sales are no higher than in other firms. SWD firms were also more likely to be larger, to be affiliated to MNEs and to export. There are no significant differences regarding the broad sectoral distribution between manufacturing and services. Only firms with in-house SWD had on average a larger proportion of employees with long university education in STEM or any other field.

\section{Results}

\subsection{Baseline models}

Table 1 presents the results from an estimation of the relationship between software development and the probability that firms introduce innovations (Eq. (1)). The table reports marginal effect from a probit estimation. Six alternative models are presented: (i) full sample, (ii) only firms in manufacturing industries, (iii) only firms in service industries, (iv) small firms (10-49 employees), (v) medium-sized firms (50-249 employees) and (vi) large firms (250+ employees). Each model also includes a test of equality of coefficients (Chi-square and significance).

It is clear from the table that there is a significant positive relationship between software development and innovation outcome. Even after controlling for several sets of control variables that are common in the empirical analyses of firm-level innovation, the estimated influence of software development on the likelihood of introducing innovations is significant. It is also evident that the relationship between software development and innovation is particularly strong for in-house software development. The marginal effect of in-house software development on innovation is stronger than the effect of external software development across all specifications. This provides support for $\mathrm{H} 2$ and is consistent with the argument that firms that develop software in-house are more deeply invested in leveraging digital technology in ways that also link to their propensity to innovate. The tests for equality of coefficient between inhouse and external software development reject the null hypothesis of a similar coefficient for the whole sample, service and small firms. This shows that the estimated marginal effect of in-house software development is indeed larger than the estimated marginal effect of external software development for these specifications. For the other models, the test does not reject the null hypothesis. However, for manufacturing and large firms, the larger statistical strength of the estimated coefficient associated with in-house than for external software development clearly indicates that inhouse software development is more strongly associated with innovation.

The main results hold across the three size classes of firms. As can been seen from models 2 and 3, there are some differences between manufacturing and services. For manufacturing firms, only in-house software development has a significant, yet weak, conditional relationship with the probability that a firm introduces innovations. Among service firms, however, both in-house and external software development is positively associated with innovation. The difference between manufacturing and services may be explained by the potential for software development to be used in different ways in different industries. 
Manufacturing firms are more likely to use software in the form of embedded software in products, as well as to improve processes, whereas for some service firms the software may constitute the actual innovation. Many firms with business models built around digital technology also operate in service industries.

Turning to the control variables, we see that the dummy for persistent $R \& D$ activity is positive and significant across all specifications, which is in line with prior studies (see, e.g., Löof et al., 2012). Temporary $R \& D$ is only significant for service firms and for small firms. R\&D intensity in the form of $R \& D$ expenses in relation to sales is insignificant across the board, with firms in manufacturing industries the only exception. One possible reason for the particular role of R\&D intensity in manufacturing could be that formal $R \& D$ is more common in manufacturing firms and that innovation in manufacturing is more dependent on a combination of, e.g., embedded software and changes in the physical attributes or functions of products, which may require formal R\&D to a greater extent.

We also find that average employee age is negatively related to innovation in the majority of specifications, which is consistent with prior studies. The proportion of employees with a long university education in STEM appears to matter most in large firms. Furthermore, we also find that exporting is positively associated with innovation in services and in small firms. In larger firms and in manufacturing, it is other factors that dominate. Firms' perceptions of the nature and competition of the markets they operate in have no relationship with innovation.

Table 2 presents the results for innovation sales, which is complementary to the analysis of the probability of innovation as it captures the commercial success of a firm's innovation (Mairesse and Mohnen, 2010). The table reports marginal effects from estimating a fractional probit model (Eq. (2)) for the same set of specifications as in Table 1. Overall, these results confirm the results in Table 1 in that it also shows a statistically significant conditional relationship between software development and innovation sales.

In-house software development is significant and positive in all specifications, with the exception of large firms. That is, firms that develop software in-house tend to have a greater proportion of their sales attributed to innovation. External software development is only significant for services and small firms, and these groups appear to drive the results for this variable in the full sample. When looking at innovation sales, we also find a pattern of a 'hierarchy' where in-house has stronger influence than external software development when looking at both statistic and economic significance. As in Table 1, the test for equality of coefficient between in-house and external software development rejects the null hypothesis of a similar coefficient for the whole sample, services and small firms, showing that the effect of in-house software development is indeed larger than external software development. For the other models, the test does not reject the null hypothesis. However, for manufacturing firms and medium-sized firms, the larger statistical strength of the estimated coefficient associated with in-house compared to external software development clearly indicates that in-house software development is more strongly associated with innovation sales.

The control variables in general exhibit results similar to those in the previous model. Persistent R\&D and average age of employees have the expected sign. For innovation sales, employees with long university education in STEM is significant in all specifications apart from mediumsized firms, which is in line with STEM employees being important for successful innovation. A difference from Table 1 is that firms' perception of the markets they operate in has a stronger relationship with innovation sales. In general, operating in markets that firms perceive to be new is a stronger predictor of the proportion of their sales attributed to innovation. This is consistent with new markets brought about by technology providing opportunities for innovation and emergent entrepreneurship (Belitski et al., 2019; Caiazza et al., 2020).

Taken together, the results reported in Tables 1 and 2 confirm our H1 and $\mathrm{H} 2$ and are consistent with a software-biased shift in innovation. Firms that develop software, and which thus are more engrained in
Table 3

In-house and external software development by use of software (\%).

\begin{tabular}{clllll}
\hline & $\begin{array}{l}\text { SW as a } \\
\text { service } \\
\text { or } \\
\text { product }\end{array}$ & $\begin{array}{l}\text { Embedded } \\
\text { SW }\end{array}$ & $\begin{array}{l}\text { SW for } \\
\text { distribution } \\
\text { or sale }\end{array}$ & $\begin{array}{l}\text { SW for } \\
\text { own } \\
\text { operations }\end{array}$ & $\begin{array}{l}\text { SW } \\
\text { development } \\
\text { service } \\
\text { (consultant) }\end{array}$ \\
\hline $\begin{array}{c}\text { In- } \\
\text { house }\end{array}$ & 92.71 & 76.37 & 54.92 & 50.97 & 94.52 \\
$\begin{array}{c}\text { External } \\
\text { Total }\end{array}$ & $\begin{array}{l}7.29 \\
\mathbf{1 0 0 . 0 0}\end{array}$ & $\begin{array}{l}23.63 \\
\mathbf{1 0 0 . 0 0}\end{array}$ & $\begin{array}{l}45.08 \\
\mathbf{1 0 0 . 0 0}\end{array}$ & $\begin{array}{l}49.03 \\
\mathbf{1 0 0 . 0 0}\end{array}$ & $\begin{array}{l}5.48 \\
\mathbf{1 0 0 . 0 0}\end{array}$ \\
\hline
\end{tabular}

Note: Each column reports the proportion of firms that developed software inhouse or by external software developers.

digitalization, appear to be in a better position to innovate, as indicated both by the probability to introduce innovations and by innovation sales. In-house software development is also more strongly linked to innovation propensity and innovation sales. It should be noted that these results are nontrivial, because software development can be used to do 'more of the same' and increase efficiency rather than to adapt to the potential of software and develop innovations.

To further probe the results and show the qualitative difference between firms that undertake in-house and external software development, respectively, Table 3 presents the distribution of firms, divided into in-house and external SWD and separated by different functions of software development in their business operations (firms that reported in-house or external software development were asked about the main use of the software that they develop).

As can be expected, firms that develop software to support their main business model (i.e., to improve internal processes or distributions and sales) rely to a higher degree on external developers, while firms that develop software that is part of their main business model (i.e., software products and services, embedded software and software development as a service) have internalized their development work to a higher degree. This does not necessarily mean that firms working with embedded software are more digitalized than firms that do not. Rather, firms that work with embedded software are more likely to have internalized their software development, signaling a more advanced use of digital technologies, than firms that develop software to improve their existing business processes.

Table 4 shows how reported innovation activities among firms are divided between firms based on their use of software development. In line with our argument and findings, the share of software-developing firms that reported innovations is larger than among the nondeveloping firms. Furthermore, the categories of firms with a higher degree of in-house developers exhibit a higher degree of reported innovation than those with a higher degree of external developers.

These findings suggest two things, both of which deserve further investigation. First, there is a difference between in-house and external software development that seems to coincide with different uses of software development. Firms that develop software to support existing business practices are more prone to using external developers and exhibit a weaker link between software development and innovation. Firms that develop software as part of their core business are more prone to hiring inhouse developers and also exhibit a stronger link between software development and innovation. This could be interpreted as a difference in the potential for innovation between different types of business activities but is also consistent with the argument that internalized software development promotes software-intensive innovation in ways that external development does not. Second, the difference between in-house and external software development may indicate a form of complementarity, rather than substitution, between the two, akin to that found in internal and external R\&D (Veugelers, 1997; Lokshin et al., 2008; Hagedoorn and Wang, 2012; Audretch and Belitski, 2020).

\subsection{Testing the role of human capital}

Based on arguments related to absorptive capacity and 
Table 4

In-house and external software development by use of software (\%).

\begin{tabular}{|c|c|c|c|c|c|c|}
\hline & $\begin{array}{l}\text { SW as a service or } \\
\text { product }\end{array}$ & $\begin{array}{l}\text { Embedded } \\
\text { SW }\end{array}$ & $\begin{array}{l}\text { SW for distribution or } \\
\text { sale }\end{array}$ & $\begin{array}{l}\text { SW for own } \\
\text { operations }\end{array}$ & $\begin{array}{l}\text { SW development service } \\
\text { (consultant) }\end{array}$ & $\begin{array}{l}\text { No SW } \\
\text { development }\end{array}$ \\
\hline Innovation & 76.56 & 73.42 & 55.25 & 47.95 & 46.58 & 31.88 \\
\hline $\begin{array}{l}\text { No } \\
\text { innovation }\end{array}$ & 23.44 & 26.58 & 44.75 & 52.05 & 53.42 & 68.12 \\
\hline Total & 100.00 & 100.00 & 100.00 & 100.00 & 100.00 & 100.00 \\
\hline
\end{tabular}

Note: Each column reports the proportion of firms that reported having introduced an innovation according to the CIS (2018).

Table 5

Probit regression by education background; dependent variable: dummy for product or service innovation.

\begin{tabular}{|c|c|c|c|c|}
\hline & \multicolumn{2}{|c|}{$\begin{array}{l}\text { Share of employees with } \\
\text { long university education } \\
\text { in STEM }\end{array}$} & \multicolumn{2}{|c|}{$\begin{array}{l}\text { Share of employees with } \\
\text { long university education, } \\
\text { except STEM }\end{array}$} \\
\hline & (1) & (2) & (3) & (4) \\
\hline & High & Low & High & Low \\
\hline \multirow{2}{*}{$\begin{array}{c}\text { In-house software } \\
\text { development }\end{array}$} & $0.203^{* * *}$ & $0.102^{* * *}$ & $0.210 * * *$ & $0.121 * * *$ \\
\hline & $(0.028)$ & $(0.028)$ & $(0.032)$ & $(0.026)$ \\
\hline \multirow{2}{*}{$\begin{array}{c}\text { External software } \\
\text { development }\end{array}$} & $0.074 *$ & $0.097 * * *$ & $0.084 *$ & $0.099 * * *$ \\
\hline & $(0.045)$ & $(0.027)$ & $(0.044)$ & (0.027) \\
\hline \multirow[t]{2}{*}{ Persistent R\&D } & $0.254 * * *$ & $0.323 * * *$ & $0.239 * * *$ & $0.357^{* * *}$ \\
\hline & $(0.036)$ & $(0.050)$ & $(0.047)$ & $(0.036)$ \\
\hline \multirow[t]{2}{*}{ Temporary R\&D } & 0.130 & $0.209 * *$ & $0.329 * * *$ & $0.186^{* * *}$ \\
\hline & $(0.093)$ & $(0.089)$ & $(0.126)$ & $(0.072)$ \\
\hline \multirow[t]{2}{*}{ R\&D expenses (\%) } & -0.000 & $2.977 * * *$ & -0.002 & 0.056 \\
\hline & $(0.000)$ & $(0.980)$ & $(0.002)$ & $(0.092)$ \\
\hline \multirow{2}{*}{$\begin{array}{l}\text { Number of employees } \\
\text { (log) }\end{array}$} & 0.001 & -0.001 & -0.015 & -0.003 \\
\hline & $(0.013)$ & $(0.009)$ & (0.013) & $(0.008)$ \\
\hline \multirow{2}{*}{$\begin{array}{l}\text { Average age of } \\
\text { employees }\end{array}$} & $-0.007 * * *$ & $-0.004 * * *$ & $-0.005^{* *}$ & $-0.004^{* * * *}$ \\
\hline & $(0.002)$ & $(0.002)$ & $(0.002)$ & $(0.002)$ \\
\hline \multirow{2}{*}{$\begin{array}{l}\text { Employees with long } \\
\text { university education in } \\
\text { STEM (\%) }\end{array}$} & 0.062 & $0.532^{*}$ & $0.349 * * *$ & -0.000 \\
\hline & $(0.074)$ & $(0.281)$ & $(0.097)$ & $(0.067)$ \\
\hline \multirow{2}{*}{$\begin{array}{l}\text { Employees with long } \\
\text { university education, } \\
\text { except STEM (\%) }\end{array}$} & -0.085 & 0.031 & $-0.377^{* * *}$ & $1.041^{* * *}$ \\
\hline & $(0.072)$ & $(0.354)$ & $(0.106)$ & $(0.299)$ \\
\hline \multirow[t]{2}{*}{ Exporter } & 0.041 & $0.059 * * *$ & $0.062^{*}$ & $0.060 * * *$ \\
\hline & $(0.032)$ & $(0.022)$ & $(0.033)$ & $(0.022)$ \\
\hline \multirow[t]{2}{*}{ MNE } & 0.031 & 0.025 & 0.038 & 0.025 \\
\hline & $(0.029)$ & $(0.023)$ & $(0.031)$ & $(0.022)$ \\
\hline $\begin{array}{l}\text { New market with high } \\
\text { competition }\end{array}$ & 0.035 & 0.094 & $0.137^{* *}$ & -0.011 \\
\hline $\begin{array}{l}\text { (ref: established market } \\
\text { with low competition) }\end{array}$ & $(0.061)$ & $(0.096)$ & $(0.069)$ & $(0.077)$ \\
\hline $\begin{array}{l}\text { New market with low } \\
\text { competition }\end{array}$ & 0.076 & 0.031 & 0.143 & 0.020 \\
\hline $\begin{array}{l}\text { (ref: established market } \\
\text { with low competition) }\end{array}$ & $(0.080)$ & $(0.073)$ & $(0.100)$ & $(0.065)$ \\
\hline $\begin{array}{l}\text { Established market with } \\
\text { high competition }\end{array}$ & -0.023 & 0.015 & 0.002 & 0.004 \\
\hline $\begin{array}{l}\text { (ref: established market } \\
\text { with low competition) }\end{array}$ & $(0.034)$ & $(0.024)$ & $(0.036)$ & $(0.023)$ \\
\hline Industry dummies & YES & YES & YES & YES \\
\hline Pseudo R-squared & 0.151 & 0.095 & 0.150 & 0.115 \\
\hline Observations & 1247 & 2683 & 1130 & 2800 \\
\hline
\end{tabular}

Note: Average marginal effects presented. Robust standard errors in parentheses. $* * *$ Significant at $1 \%$ level; $* *$ significant at $5 \%$ level; * significant at $10 \%$ level.

complementarity between human capital and digital technology, our second hypothesis is that the relationship between software development and innovation is stronger in firms with stronger absorptive capacity, as reflected by their workforce's level of human capital. To test this in our empirical context, we follow Niebel et al. (2019) and divide the sample of firms into two groups: (i) firms with an above-average proportion of
Table 6

Fractional probit regression by education background, dependent variable: innovation sales (\%).

\begin{tabular}{|c|c|c|c|c|}
\hline & \multicolumn{2}{|c|}{$\begin{array}{l}\text { Share of employees with } \\
\text { long university education } \\
\text { in STEM }\end{array}$} & \multicolumn{2}{|c|}{$\begin{array}{l}\text { Share of employees with } \\
\text { long university education, } \\
\text { except STEM }\end{array}$} \\
\hline & (1) & (2) & (3) & (4) \\
\hline & High & Low & High & Low \\
\hline \multirow{2}{*}{$\begin{array}{l}\text { In-house software } \\
\text { development }\end{array}$} & $0.069 * * *$ & $0.019 * *$ & $0.051 * * *$ & $0.035 * * *$ \\
\hline & $(0.013)$ & $(0.008)$ & $(0.013)$ & $(0.008)$ \\
\hline \multirow{2}{*}{$\begin{array}{c}\text { External software } \\
\text { development }\end{array}$} & 0.021 & $0.016^{*}$ & 0.013 & $0.018^{*}$ \\
\hline & $(0.021)$ & $(0.008)$ & $(0.018)$ & $(0.009)$ \\
\hline \multirow[t]{2}{*}{ Persistent R\&D } & $0.065^{* * *}$ & $0.054^{* * *}$ & $0.055^{* * *}$ & $0.057 * * *$ \\
\hline & $(0.015)$ & $(0.010)$ & $(0.017)$ & $(0.009)$ \\
\hline \multirow[t]{2}{*}{ Temporary R\&D } & 0.001 & $0.050 * *$ & 0.023 & $0.035^{*}$ \\
\hline & $(0.032)$ & $(0.021)$ & $(0.033)$ & $(0.020)$ \\
\hline \multirow[t]{2}{*}{ R\&D expenses (\%) } & 0.000 & $0.223^{* * *}$ & $-0.000 *$ & $0.042^{* *}$ \\
\hline & $(0.000)$ & $(0.076)$ & $(0.000)$ & $(0.018)$ \\
\hline \multirow{2}{*}{$\begin{array}{l}\text { Number of employees } \\
\text { (log) }\end{array}$} & $-0.015^{* * *}$ & $-0.010^{* * *}$ & $-0.015^{* * *}$ & $-0.010^{* * *}$ \\
\hline & $(0.006)$ & $(0.003)$ & $(0.006)$ & $(0.003)$ \\
\hline \multirow{2}{*}{$\begin{array}{l}\text { Average age of } \\
\text { employees }\end{array}$} & $-0.004 * * *$ & $-0.002^{* * *}$ & $-0.003^{* * *}$ & $-0.002^{* * *}$ \\
\hline & $(0.001)$ & $(0.000)$ & $(0.001)$ & $(0.001)$ \\
\hline \multirow{2}{*}{$\begin{array}{l}\text { Employees with long } \\
\text { university education in } \\
\text { STEM (\%) }\end{array}$} & $0.057^{*}$ & 0.038 & $0.081 * *$ & $0.039 *$ \\
\hline & $(0.032)$ & $(0.082)$ & $(0.033)$ & $(0.020)$ \\
\hline \multirow{2}{*}{$\begin{array}{l}\text { Employees with long } \\
\text { university education, } \\
\text { except STEM (\%) }\end{array}$} & $-0.102^{* * *}$ & 0.062 & $-0.139 * * *$ & 0.027 \\
\hline & $(0.031)$ & $(0.105)$ & $(0.038)$ & $(0.099)$ \\
\hline \multirow[t]{2}{*}{ Exporter } & $0.029 * *$ & $0.018 * *$ & $0.024 *$ & $0.020 * *$ \\
\hline & $(0.015)$ & $(0.007)$ & $(0.014)$ & $(0.008)$ \\
\hline \multirow[t]{2}{*}{ MNE } & 0.005 & 0.000 & 0.007 & -0.001 \\
\hline & $(0.013)$ & $(0.007)$ & $(0.012)$ & $(0.007)$ \\
\hline $\begin{array}{l}\text { New market with high } \\
\text { competition }\end{array}$ & 0.034 & 0.012 & 0.038 & 0.016 \\
\hline $\begin{array}{l}\text { (ref: established market } \\
\text { with low competition) }\end{array}$ & $(0.023)$ & $(0.019)$ & $(0.023)$ & $(0.019)$ \\
\hline $\begin{array}{l}\text { New market with low } \\
\text { competition }\end{array}$ & $0.094^{* * *}$ & 0.005 & $0.135^{* * *}$ & -0.000 \\
\hline $\begin{array}{l}\text { (ref: established market } \\
\text { with low competition) }\end{array}$ & $(0.033)$ & $(0.020)$ & $(0.035)$ & $(0.019)$ \\
\hline $\begin{array}{l}\text { Established market with } \\
\text { high competition }\end{array}$ & -0.004 & 0.009 & 0.018 & 0.001 \\
\hline $\begin{array}{l}\text { (ref: established market } \\
\text { with low competition) }\end{array}$ & $(0.014)$ & $(0.008)$ & $(0.014)$ & $(0.008)$ \\
\hline Industry dummies & YES & YES & YES & YES \\
\hline Observations & 1247 & 2683 & 1130 & 2800 \\
\hline
\end{tabular}

Note: Average marginal effects presented. Robust standard errors in parentheses. $* * *$ Significant at $1 \%$ level; ** significant at $5 \%$ level; * significant at $10 \%$ level.

employees with a long university education in STEM and (ii) firms with a below-average proportion of the same type of employee. We then run separate estimations for both groups. If the estimated marginal effect of software development is larger in the former than in the latter group, this is consistent with firms' ability to leverage the innovation potential of software development being related to its human capital. We do a similar grouping of firms based on the proportion of employees with a long 
university education in other fields and also run separate estimations on these groups. In this way, we can test whether possible complementarity pertains to both types of human capital.

Table 5 presents the results for the probability to introduce innovations. The first two columns distinguish between firms with high (column 1) and low (column 2) proportions of employees with a university education in STEM. The second set of columns distinguishes between firms with high (column 3) and low (column 4) proportions of employees with a long university education in fields other than STEM.

Comparing the estimated marginal effect between columns 1 and 2 and between columns 3 and 4, it is clear that our third hypothesis is confirmed in the case of in-house software development. The estimated marginal effect of software development in the probability to introduce innovations is significantly larger among the group of firms with an above-average proportion of employees with long university educations in STEM and in other fields, respectively. This is consistent with the hypothesis that there is complementarity between human capital and digital technology in the sense that human capital is needed to leverage the full innovation potential of new technology. The results here suggest that this complementarity applies not only to human capital in STEM, which is normally associated with new technology and digitalization, but also with human capital in the form of education in other fields.

Looking instead at external software development, the pattern is reversed. The marginal effect of external software development is somewhat higher for firms with a low proportion of employees with a long university education in STEM and in other fields, although the differences are rather small in quantitative terms. One explanation for this is that issues of human capital complementarity and absorptive capacity primarily pertain to firms more deeply engrained in digitalization, as reflected by in-house software development.

Table 6 presents estimations based on the same breakdown of firms for the case of innovation sales. All results are from an estimation of a fractional probit model. The results confirm the results in Table 5. The estimated marginal effect of in-house software development on innovation sales is significantly higher among firms with an above-average proportion of employees with long university educations in STEM (columns 1 and 2) and in other fields (columns 3 and 4). For external software development, the differences in the estimated marginal effects between the groups of firms is negligible. This reinforces the previous interpretation: issues of human capital complementarity and absorptive capacity appear to primarily pertain to firms more deeply engrained in digitalization, as reflected by in-house software development. Taken together, the results in both tables support the second hypothesis.

To further probe the results in Tables 5 and 6, we also present estimations of the models with interactions between in-house and external software development, respectively, the proportion of employees with a long university education in STEM and the proportion of employees with a long university education in other disciplines or subjects. This is because in this way we can test whether there are statistically significant differences in the estimated influence of software development on innovation linked to the proportion of workers in firms with a long university education in STEM and other fields, respectively. The results of this undertaking are presented in Table A. 4 in the appendix. The main results are that the patterns in Tables 5 and 6 are also visible using interaction terms. However, only two results are statistically significant: (i) the marginal effect of in-house software development is greater if the firm has a larger proportion of workers with a long university education in fields other than STEM and (ii) the marginal effect of in-house software development on innovation sales in firms with a larger proportion of workers with a long university education in STEM. Overall, these results support the ability of the education level of a firm's workers to mediate the influence that software development has on innovation.

\section{Summary and conclusions}

body of empirical evidence that speaks to the conclusion that there is a software bias in innovation across the entire economy. More to the point, we show that firms that engage in software development, especially those with in-house software developers, report higher levels of innovation output and can attribute a larger share of their sales to innovation. These results hold for both manufacturing and service firms and firms of different sizes, clearly indicating that software development and its relationship with innovation is not confined to a subset of the economy but is pervasive. This is consistent with the expectation that digitalization introduces a new GPT into the economy.

Furthermore, firms with higher shares of university-educated employees exhibit a stronger relationship between software development, especially in firms with in-house software developers, and innovation propensity, in line with the notion of absorptive capacity. Interestingly, these results hold not only for employees with STEM educations but also for other types of university degrees, including 'softer' disciplines that are not normally associated with technology and digitalization. A general remark based on these findings is that, while technological skills might be necessary to leverage digital technologies in business activities, it may not be sufficient. On the contrary: there appears to be great value in complementary skill sets. Since the future need for so-called digital skills is becoming an increasingly prioritized policy issue, this warrants further investigation.

The results not only indicate that software development is important to innovation activities but also suggest that reported innovation activities exhibit a corresponding bias toward integrating and leveraging digital technologies in business activities, in line with Brynjolfsson and Hitt's (2000) notion of complementary innovations. Put differently, while the number of firms engaging in software development are in the minority in the Swedish economy, they may play a key role in both facilitating digitalization and contributing to innovation.

An increasing use of software and software development in economic activities and innovation can be described in one of two ways. First, it indicates a growing software-intensity, whereby firms use software and digital technologies to gain productivity benefits or competitive advantage. Second, it implies that businesses are becoming increasingly dependent on different types of software infrastructure, some of which cross organizational boundaries or are supplied by third parties (e.g., cloud services). Both of these developments contribute to a structural transformation of the economy that entails both innovation potential and new types of risk related to interconnectedness and interdependencies. Furthermore, a shift toward software in innovation may significantly alter the conditions of the tradeoff between software development and buying standardized software off the shelf across different sectors and business functions. All of this calls for further investigation in future research.

\section{Author statement}

All authors contributed equally.

\section{Acknowledgements}

We are grateful for constructive comments from the editors of the special issue, from two anonymous reviewers, and from Claudio Fassio, Maksim Belitski, Reinhilde Veugelers, David Audretsch, Krzysztof Wnuk and seminar participants at the conference "From Startup to Scale-Up: Entrepreneurship, Human Capital, Innovation \& Scaling Up New Businesses" in October 2018 in Stockholm, as well as the "Creative Spark Workshop 2020" in Berlin, Germany.

\section{Appendix}

Table A1, Table A2, Table A3 and Table A4

The evidence presented in this paper adds to a small but growing 
Table A.1

Summary statistics.

\begin{tabular}{|c|c|c|c|c|c|}
\hline & $\mathrm{N}$ & Mean & SD & Min & Max \\
\hline Product innovation & 3947 & 0.41 & 0.49 & 0 & 1 \\
\hline Innovation sales (\%) & 3947 & 0.09 & 0.18 & 0 & 1 \\
\hline In-house software development & 3947 & 0.21 & 0.41 & 0 & 1 \\
\hline External software development & 3947 & 0.11 & 0.32 & 0 & 1 \\
\hline No software development & 3947 & 0.68 & 0.47 & 0 & 1 \\
\hline Persistent R\&D & 3947 & 0.09 & 0.30 & 0 & 1 \\
\hline Temporary R\&D & 3947 & 0.01 & 0.12 & 0 & 1 \\
\hline R\&D expenses (\%) & 3930 & 0.48 & 14.9 & 0 & 674.00 \\
\hline Small (10-49) & 3947 & 0.60 & 0.49 & 0 & 1 \\
\hline Medium (50-249) & 3947 & 0.31 & 0.46 & 0 & 1 \\
\hline Large $(250+)$ & 3947 & 0.09 & 0.29 & 0 & 1 \\
\hline Number of employees (log) & 3947 & 3.75 & 1.21 & 2.30 & 10.00 \\
\hline Average age of employees & 3947 & 41.2 & 5.95 & 21.4 & 69.9 \\
\hline Employees with long university education in STEM (\%) & 3947 & 0.19 & 0.23 & 0 & 1 \\
\hline Employees with long university education, except STEM (\%) & 3947 & 0.09 & 0.15 & 0 & 0.97 \\
\hline Exporter & 3947 & 0.45 & 0.50 & 0 & 1 \\
\hline MNE & 3947 & 0.36 & 0.48 & 0 & 1 \\
\hline New market with high competition & 3947 & 0.03 & 0.17 & 0 & 1 \\
\hline New market with low competition & 3947 & 0.02 & 0.15 & 0 & 1 \\
\hline Established market with high competition & 3947 & 0.77 & 0.42 & 0 & 1 \\
\hline Established market with low competition & 3947 & 0.16 & 0.37 & 0 & 1 \\
\hline Manufacturing & 3947 & 0.30 & 0.46 & 0 & 1 \\
\hline Services & 3947 & 0.70 & 0.46 & 0 & 1 \\
\hline
\end{tabular}

Table A.2

Difference in means between firms according to software development activity.

\begin{tabular}{|c|c|c|c|c|c|c|c|c|c|}
\hline & \multicolumn{3}{|c|}{ External software development } & \multicolumn{3}{|c|}{ In-house software development } & \multicolumn{3}{|c|}{ In-house and external software development } \\
\hline & $\begin{array}{l}(1) \\
\text { Mean } \\
\text { external }\end{array}$ & $\begin{array}{l}(2) \\
\text { Mean no } \\
\text { SWD }\end{array}$ & $\begin{array}{l}(3) \\
\text { Diff of mean }(1) \\
-(2)\end{array}$ & $\begin{array}{l}(4) \\
\text { Mean in- } \\
\text { house }\end{array}$ & $\begin{array}{l}(5) \\
\text { Mean no } \\
\text { SWD }\end{array}$ & $\begin{array}{l}(6) \\
\text { Diff of mean (5) - } \\
(4)\end{array}$ & $\begin{array}{l}(7) \\
\text { Mean in- } \\
\text { house }\end{array}$ & $\begin{array}{l}\text { (8) } \\
\text { Mean } \\
\text { external }\end{array}$ & $\begin{array}{l}\text { (9) } \\
\text { diff of mean (7) } \\
-(8)\end{array}$ \\
\hline Innovation & 0.46 & 0.32 & $\begin{array}{l}0.146^{* * * *} \\
(6.03)\end{array}$ & 0.65 & 0.32 & $\begin{array}{l}0.332^{* * *} \\
(17.81)\end{array}$ & 0.65 & 0.46 & $\begin{array}{l}0.186^{* * *} \\
(6.50)\end{array}$ \\
\hline Innovation sales & 0.085 & 0.063 & $\begin{array}{l}0.022^{* *} \\
(2.85)\end{array}$ & 0.16 & 0.063 & $\begin{array}{l}0.100 * * * \\
(14.75)\end{array}$ & 0.16 & 0.085 & $\begin{array}{l}0.079 * * * \\
(6.19)\end{array}$ \\
\hline Persistent R\&D & 0.10 & 0.046 & $\begin{array}{l}0.058^{* * *} \\
(4.97)\end{array}$ & 0.26 & 0.046 & $\begin{array}{l}0.215^{* * *} \\
(19.17)\end{array}$ & 0.26 & 0.10 & $\begin{array}{l}0.157^{* * *} \\
(6.69)\end{array}$ \\
\hline Temporary R\&D & 0.011 & 0.008 & $\begin{array}{l}0.002 \\
(0.39)\end{array}$ & 0.031 & 0.009 & $\begin{array}{l}0.022^{* * * *} \\
(4.62)\end{array}$ & 0.031 & 0.011 & $\begin{array}{l}0.020^{*} \\
(2.20)\end{array}$ \\
\hline R\&D expenses (\%) & 0.43 & 0.34 & $\begin{array}{l}0.084 \\
(0.13)\end{array}$ & 0.96 & 0.34 & $\begin{array}{l}0.62 \\
(1.00)\end{array}$ & 0.96 & 0.43 & $\begin{array}{l}0.53 \\
(0.52)\end{array}$ \\
\hline Small (10-49) & 0.48 & 0.67 & $\begin{array}{l}-0.191 * * * \\
(-7.84)\end{array}$ & 0.44 & 0.67 & $\begin{array}{l}-0.229 * * * \\
(-12.08)\end{array}$ & 0.44 & 0.48 & $\begin{array}{l}-0.038 \\
(-1.28)\end{array}$ \\
\hline Medium (50-249) & 0.37 & 0.28 & $\begin{array}{l}0.085^{* * *} \\
(3.61)\end{array}$ & 0.37 & 0.28 & $\begin{array}{l}0.082^{* * *} \\
(4.58)\end{array}$ & 0.37 & 0.37 & $\begin{array}{l}-0.001 \\
(-0.04)\end{array}$ \\
\hline Large $(250+)$ & 0.16 & 0.049 & $\begin{array}{l}0.107 * * * \\
(8.56)\end{array}$ & 0.20 & 0.049 & $\begin{array}{l}0.146^{* * * *} \\
(13.56)\end{array}$ & 0.20 & 0.16 & $\begin{array}{l}0.039 \\
(1.70)\end{array}$ \\
\hline Number of employees (log) & 4.11 & 3.54 & $\begin{array}{l}0.572^{* * *} \\
(10.11)\end{array}$ & 4.22 & 3.54 & $\begin{array}{l}0.684 * * * \\
(15.01)\end{array}$ & 4.22 & 4.11 & $\begin{array}{l}0.112 \\
(1.39)\end{array}$ \\
\hline Average age of employees & 41.14 & 41.55 & $\begin{array}{l}0.397 \\
(0.310)\end{array}$ & 41.14 & 41.12 & $\begin{array}{l}-0.033 \\
(-0.14)\end{array}$ & 41.12 & 41.55 & $\begin{array}{l}-0.429 \\
(-1.31)\end{array}$ \\
\hline $\begin{array}{l}\text { Employees with long university education } \\
\text { in STEM (\%) }\end{array}$ & 0.15 & 0.15 & $\begin{array}{l}0.002 \\
(0.33)\end{array}$ & 0.34 & 0.15 & $\begin{array}{l}0.184 * * * \\
(21.07)\end{array}$ & 0.34 & 0.15 & $\begin{array}{l}0.181^{* * *} \\
(13.07)\end{array}$ \\
\hline $\begin{array}{l}\text { Employees with long university education, } \\
\text { except STEM (\%) }\end{array}$ & 0.097 & 0.090 & $\begin{array}{l}0.007 \\
(0.89)\end{array}$ & 0.13 & 0.090 & $\begin{array}{l}0.036 * * * \\
(6.38)\end{array}$ & 0.13 & 0.097 & $\begin{array}{l}0.031 * * * \\
(3.66)\end{array}$ \\
\hline Export dummy & 0.54 & 0.38 & $\begin{array}{l}0.160^{* * *} \\
(6.39)\end{array}$ & 0.61 & 0.38 & $\begin{array}{l}0.230 * * * \\
(11.91)\end{array}$ & 0.61 & 0.54 & $\begin{array}{l}0.070^{*} \\
(2.41)\end{array}$ \\
\hline MNE & 0.43 & 0.28 & $\begin{array}{l}0.148^{* * *} \\
(6.30)\end{array}$ & 0.58 & 0.28 & $\begin{array}{l}0.298^{* * *} \\
(16.25)\end{array}$ & 0.58 & 0.43 & $\begin{array}{l}0.150^{* * * *} \\
(5.14)\end{array}$ \\
\hline New market with high competition & 0.025 & 0.018 & $\begin{array}{l}0.007 \\
(0.99)\end{array}$ & 0.076 & 0.018 & $\begin{array}{l}0.058^{* * *} \\
(8.40)\end{array}$ & 0.076 & 0.025 & $\begin{array}{l}0.051^{* * *} \\
(3.71)\end{array}$ \\
\hline New market with low competition & 0.029 & 0.017 & $\begin{array}{l}0.011 \\
(1.75)\end{array}$ & 0.043 & 0.017 & $\begin{array}{l}0.025^{* * *} \\
(4.36)\end{array}$ & 0.043 & 0.029 & $\begin{array}{l}0.014 \\
(1.22)\end{array}$ \\
\hline Established market with high competition & 0.77 & 0.79 & $\begin{array}{l}-0.016 \\
(-0.75)\end{array}$ & 0.72 & 0.79 & $\begin{array}{l}-0.065^{* * *} \\
(-3.98)\end{array}$ & 0.72 & 0.77 & $\begin{array}{l}-0.050 \\
(-1.95)\end{array}$ \\
\hline Established market with low competition & 0.17 & 0.17 & $\begin{array}{l}0.003 \\
(0.15)\end{array}$ & 0.15 & 0.17 & $\begin{array}{l}-0.014 \\
(-1.04)\end{array}$ & 0.15 & 0.17 & $\begin{array}{l}-0.018 \\
(-0.85)\end{array}$ \\
\hline Manufacturing & 0.34 & 0.29 & $\begin{array}{l}0.046 \\
(1.95)\end{array}$ & 0.30 & 0.29 & $\begin{array}{l}0.006 \\
(0.39)\end{array}$ & 0.30 & 0.34 & $\begin{array}{l}-0.039 \\
(-1.42)\end{array}$ \\
\hline Services & 0.66 & 0.71 & $\begin{array}{l}-0.046 \\
(-1.95)\end{array}$ & 0.70 & 0.71 & $\begin{array}{l}-0.006 \\
(-0.39)\end{array}$ & 0.70 & 0.66 & $\begin{array}{l}0.039 \\
(1.42)\end{array}$ \\
\hline
\end{tabular}

Note: $* * *$ significant at $1 \%$ level; $* *$ significant at $5 \%$ level; $*$ significant at $10 \%$ level. 
Table A.3

Matrix of correlations.

\begin{tabular}{|c|c|c|c|c|c|c|c|c|c|c|c|c|c|c|c|c|}
\hline Variables & (1) & (2) & (3) & (4) & (5) & (6) & (7) & (8) & (9) & (10) & (11) & (12) & (13) & (14) & (15) & (16) \\
\hline (1) Product innovation & 1.0000 & & & & & & & & & & & & & & & \\
\hline $\begin{array}{l}\text { (2) Innovation sales } \\
(\%)\end{array}$ & $0.5980^{*}$ & 1.0000 & & & & & & & & & & & & & & \\
\hline (3) In-house SWD & $0.2575^{*}$ & $0.2242 *$ & 1.0000 & & & & & & & & & & & & & \\
\hline (4) External SWD & $0.0428^{*}$ & -0.0043 & $-0.1830^{*}$ & 1.0000 & & & & & & & & & & & & \\
\hline (5) Persistent R\&D & $0.2773^{*}$ & $0.2387^{*}$ & $0.2820^{*}$ & 0.0068 & 1.0000 & & & & & & & & & & & \\
\hline (6) Temporary R\&D & $0.0754 *$ & $0.0503^{*}$ & $0.0748^{*}$ & -0.0085 & $-0.0397^{*}$ & 1.0000 & & & & & & & & & & \\
\hline (7) R\&D expenses (\%) & 0.0083 & $0.0724^{*}$ & 0.0166 & -0.0013 & $0.0615^{*}$ & -0.0037 & 1.0000 & & & & & & & & & \\
\hline $\begin{array}{l}\text { (8) Number of } \\
\text { employees (log) }\end{array}$ & $0.0978^{*}$ & -0.0276 & $0.2032^{*}$ & $0.1067^{*}$ & $0.1632^{*}$ & 0.0047 & -0.0216 & 1.0000 & & & & & & & & \\
\hline $\begin{array}{l}\text { (9) Average age of } \\
\text { employees }\end{array}$ & -0.0170 & $-0.0551^{*}$ & -0.0060 & 0.0215 & $0.1045^{*}$ & 0.0006 & 0.0118 & $-0.0470^{*}$ & 1.0000 & & & & & & & \\
\hline $\begin{array}{l}\text { (10) Employees with } \\
\text { long university } \\
\text { education in STEM } \\
(\%)\end{array}$ & $0.1792^{*}$ & $0.2095^{*}$ & $0.3280^{*}$ & $-0.0554^{*}$ & $0.2818^{*}$ & $0.0386^{*}$ & $0.0611^{*}$ & -0.0093 & -0.0042 & 1.0000 & & & & & & \\
\hline $\begin{array}{l}\text { (11) Employees with } \\
\text { long university } \\
\text { education, except } \\
\text { STEM (\%) }\end{array}$ & $0.0628^{*}$ & $0.0485^{*}$ & $0.1009^{*}$ & -0.0043 & $0.0576^{*}$ & -0.0093 & $0.0421 *$ & $-0.0313^{*}$ & -0.0224 & $0.6748^{*}$ & 1.0000 & & & & & \\
\hline (12) Exporter & $0.1855^{*}$ & 0.1034 * & $0.1697^{*}$ & $0.0667^{*}$ & $0.2333^{*}$ & $0.0647^{*}$ & -0.0087 & $0.2578^{*}$ & $0.2078^{*}$ & 0.0073 & $-0.0639 *$ & 1.0000 & & & & \\
\hline (13) MNE & $0.1775^{*}$ & $0.0858 *$ & $0.2348^{*}$ & $0.0508^{*}$ & $0.2231 *$ & $0.0389^{*}$ & 0.0241 & $0.4053^{*}$ & $0.0880^{*}$ & $0.1856^{*}$ & $0.0972^{*}$ & $0.4045 *$ & 1.0000 & & & \\
\hline $\begin{array}{l}\text { (14) New market with } \\
\text { high competition }\end{array}$ & 0.0999* & $0.1280^{*}$ & $0.1342^{*}$ & -0.0122 & $0.1669^{*}$ & 0.0157 & 0.0147 & -0.0250 & $-0.0702^{*}$ & $0.2009^{*}$ & $0.0977^{*}$ & 0.0105 & $0.0695^{*}$ & 1.0000 & & \\
\hline $\begin{array}{l}\text { (15) New market with } \\
\text { low competition }\end{array}$ & $0.0521^{*}$ & $0.1122^{*}$ & $0.0650^{*}$ & 0.0125 & $0.0756^{*}$ & $0.0371^{*}$ & $0.1435^{*}$ & $-0.0811^{*}$ & -0.0351 * & $0.0832^{*}$ & $0.0390^{*}$ & 0.0087 & $-0.0358^{*}$ & -0.0280 & 1.0000 & \\
\hline $\begin{array}{l}\text { (16) Established } \\
\text { market with high } \\
\text { competition }\end{array}$ & $-0.0324 *$ & $-0.0643^{*}$ & $-0.0607^{*}$ & 0.0009 & $-0.0900 *$ & -0.0115 & $-0.0458^{*}$ & $0.1313^{*}$ & $-0.0567^{*}$ & $-0.1116^{*}$ & $-0.0335^{*}$ & 0.0171 & $0.0635 *$ & $-0.3288^{*}$ & $-0.2892^{*}$ & 1.0000 \\
\hline
\end{tabular}

Note: * significant at $5 \%$ level. 
Table A.4

Results using interactions between software development and education level of workers.

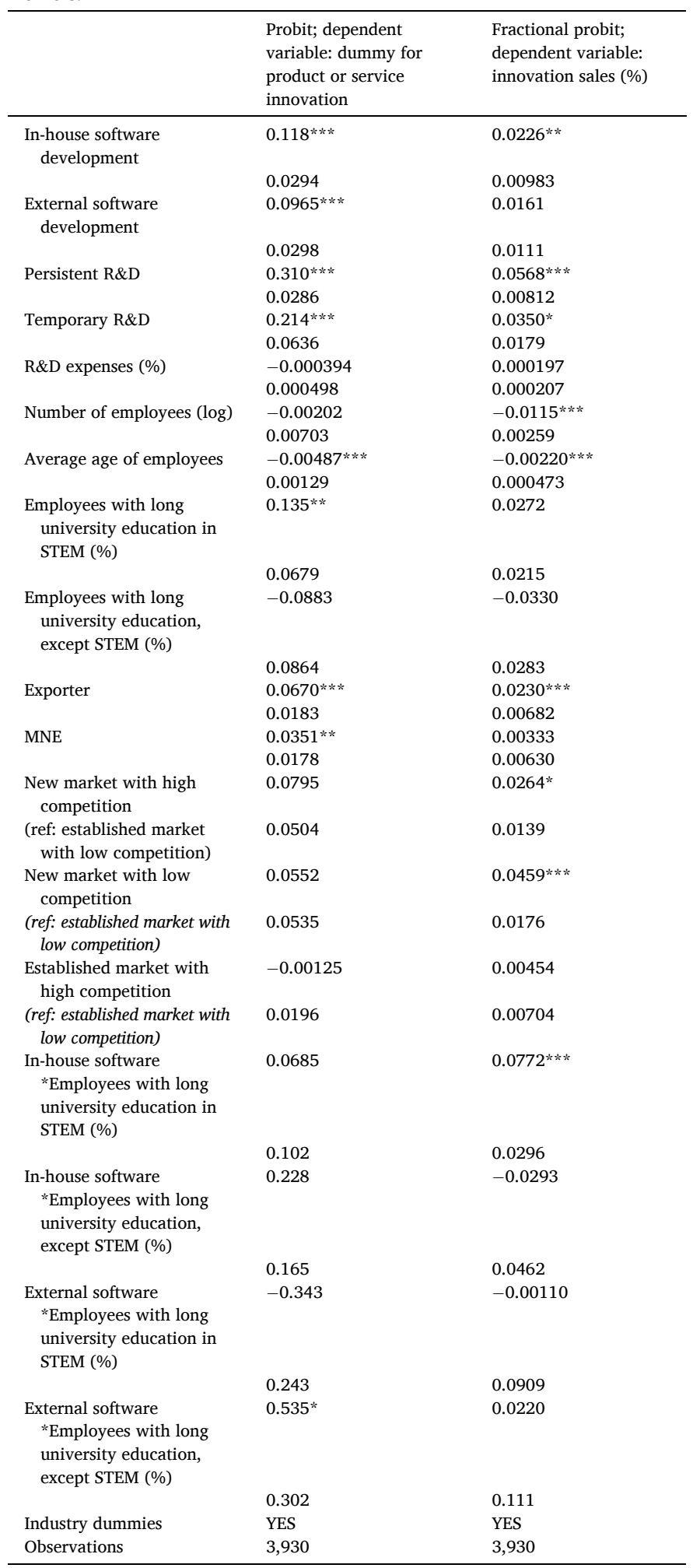

Note: Average marginal effects presented. Robust standard errors in parentheses. $* *$ Significant at $1 \%$ level; ** significant at $5 \%$ level; * significant at $10 \%$ level.

\section{References}

Acs, Z.J., Audretsch, D.B., 1988. Innovation in large and small firms: an empirical analysis. Am. Econ. Rev. 78 (4), 678-690.

Andersson, M., Kusetogullari, A., Wernberg, J., 2020. Who is going soft? Software Development in Swedish Firms, Working Papers. Blekinge Institute of Technology, Karlskrona.

Andersson, M., Lööf, H., 2009. Learning-by-exporting revisited: the role of intensity and persistence. Scand. J. Econ. 111 (4), 893-916.

Arora, A., Branstetter, L.G., Drev, M., 2013. Going soft: how the rise of software-based innovation led to the decline of Japan's IT industry and the resurgence of Silicon valley. Rev. Econ. Stat. 95 (3), 757-775.

Arora, A., Gambardella, A., 1994. The changing technology of technological change: general and abstract knowledge and the division of innovative labour. Res. Policy 23 (5), 523-532.

Audretsch, D.B., Belitski, M., 2020. The role of R\&D and knowledge spillovers in innovation and productivity. Eur. Econ. Rev. 123, 103391.

Autor, D.H., Levy, F., Murnane, R.J., 2003. The skill content of recent technological change: an empirical exploration. Q. J. Econ. 118 (4), 1279-1333.

Belitski, M., Caiazza, R., Lehmann, E.E., 2019. Knowledge frontiers and boundaries in entrepreneurship research. Small Bus. Econ. forthcoming.

Bessen, J., Hunt, R.M., 2007. An empirical look at software patents. J. Econ. Manag. Strategy 16 (1), 157-189.

Branstetter, L.G., Drev, M., Kwon, N., 2019. Get with the program: software-driven innovation in traditional manufacturing. Manag. Sci. 65 (2), 541-558.

Bresnahan, T.F., Brynjolfsson, E., Hitt, L.M., 2002. Information technology, workplace organization, and the demand for skilled labor: firm-level evidence. Q. J. Econ. 117 (1), 339-376.

Bresnahan, T.F., Trajtenberg, M., 1995. General purpose technologies 'engines of growth'? J. Econ. 65 (1), 83-108.

Brynjolfsson, E., Hitt, L.M., 2000. Beyond computation: information technology, organizational transformation and business performance. J. Econ. Perspect. 14 (4), 23-48.

Brynjolfsson, E., Hitt, L.M., Yang, S., 2002. Intangible assets: computers and organizational capital. Brook. Pap. Econ. Act. 2002 (1), 137-181.

Brynjolfsson, E., McAfee, A., 2014. The Second Machine Age: Work, Progress, and Prosperity in a Time of Brilliant Technologies. WW Norton \& Company.

Brynjolfsson, E., Saunders, A., 2009. Wired for Innovation: How Information Technology is Reshaping the Economy. MIT Press.

Caiazza, R., Belitski, M., Audretsch, D.B., 2020. From latent to emergent entrepreneurship: the knowledge spillover construction circle. J. Technol. Transf. forthcoming.

Caiazza, R., Richardson, A., Audretsch, D., 2015. Knowledge effects on competitiveness: from firms to regional advantage. J. Technol. Transf. 40 (6), 899-909.

Cantwell, J., Iammarino, S., 2005. The technological innovation of multinational corporations in the French regions. Rev. Écon. Ind. 109 (1), 9-28.

Cassiman, B., Golovko, E., 2011. Innovation and internationalization through exports. J. Int. Bus. Stud. 42 (1), 56-75.

Chung, S., Animesh, A., Han, K., Pinsonneault, A., 2019. Software patents and firm value: A real options perspective on the role of innovation orientation and environmental uncertainty. Inf. Syst. Res. 30 (3), 1073-1097.

Cockburn, I.M., Henderson, R.M., 1998. Absorptive capacity, coauthoring behavior, and the organization of research in drug discovery. J. Ind. Econ. 46 (2), 157-182.

Cohen, W.M., 2010. Fifty years of empirical studies of innovative activity and performance. Handb. Econ. Innovation 1, 129-213.

Cohen, W.M., Levinthal, D.A., 1990. Absorptive capacity: a new perspective on learning and innovation. Adm. Sci. Q. 128-152.

Colombelli, A., Haned, N., Le Bas, C., 2013. On firm growth and innovation: some new empirical perspectives using French CIS (1992-2004). Struct. Change Econ. Dyn. 26, 14-26.

Ebert, C., 2007. The impacts of software product management. J. Syst. Softw. 80 (6), $850-861$.

Ebert, C., Jones, C., 2009. Embedded software: facts, figures, and future. Computer 42 (4), 42-52.

Edquist, H., Henrekson, M., 2017a. Do R\&D and ICT affect total factor productivity growth differently? Telecommun. Policy 41 (2), 106-119.

Edquist, H., Henrekson, M., 2017b. Swedish lessons: how important are ICT and R\&D to economic growth? Struct. Change Econ. Dyn. 42, 1-12.

Engelstätter, B., 2012. It is not all about performance gains-enterprise software and innovations. Econ. Innov. New Technol. 21 (3), 223-245.

Engelstätter, B., Sarbu, M., 2013. Does enterprise software matter for service innovation? Standardization versus customization. Econ. Innov. New Technol. 22 (4), 412-429.

Evans, D.S., Schmalensee, R., 2016. Matchmakers: The New Economics of Multisided Platforms. Harvard Business Review Press.

Ezell, S. J., Atkinson, R. D., Kim, I., \& Cho, J. (2018). Manufacturing digitalization: extent of adoption and recommendations for increasing penetration in Korea and the US. Available at SSRN: https://ssrn.com/abstract $=3264125$.

Fassio, C., 2018. Export-led innovation: the role of export destinations. Ind. Corp. Change 27 (1), 149-171.

Freel, M.S., 2003. Sectoral patterns of small firm innovation, networking and proximity, Res. Policy 32 (5), 751-770.

Frenz, M., Ietto-Gillies, G., 2007. Does multinationality affect the propensity to innovate? An analysis of the third UK community innovation survey. Int. Rev. Appl. Econ. 21 (1), 99-117. 
Grimm, K., 2003. Software technology in an automotive company-major challenges. In: Proceedings of the 25th International Conference on Software Engineering. IEEE pp. 498-503.

Hagedoorn, J., Wang, N., 2012. Is there complementarity or substitutability between internal and external R\&D strategies? Res. Policy 41 (6), 1072-1083.

Hall, B.H., Lotti, F., Mairesse, J., 2013. Evidence on the impact of R\&D and ICT investments on innovation and productivity in Italian firms. Econ. Innov. New Technol. 22 (3), 300-328.

Hall, B.H., MacGarvie, M., 2010. The private value of software patents. Res. Policy 39 (7), 994-1009.

Haskel, J., Westlake, S., 2018. Capitalism Without Capital: The Rise of the Intangible Economy. Princeton University Press.

Hempell, T., 2003. Do Computers Call for Training? Firm-Level Evidence on Complementarities Between ICT and Human Capital Investments. Zentrum für Europäische Wirtschaftsforschung GmbH. ZEW Discussion Papers, Mannheim, Germany. No. 03-20.

Iansiti, M., Lakhani, K.R., 2014. Digital ubiquity: how connections, sensors, and data are revolutionizing business. Harv. Bus. Rev. 92 (11), 19.

Kim, K., Lee, J., \& Gopal, A. (2019). Soft but strong: software-based innovation, product market competition, and value creation in the IT hardware industry. Working paper, November 18, 2019.

Kleis, L., Chwelos, P., Ramirez, R.V., Cockburn, I., 2012. Information technology and intangible output: the impact of IT investment on innovation productivity. Inf. Syst. Res. 23 (1), 42-59.

Lokshin, B., Belderbos, R., Carree, M., 2008. The productivity effects of internal and external R\&D: evidence from a dynamic panel data model. Oxf. Bull. Econ. Stat. 70 (3), 399-413.

Lööf, H., Johansson, B., Andersson, M., Karlsson, C., 2012. R\&D strategy and firm performance: what is the long-run impact of persistent R\&D? In: Andersson, M., Johansson, B., Karlsson, C, Löof, H. (Eds.), Innovation and Growth - From R\&D Strategies of Innovating Firms to Economy-Wide Technological Change. Oxford University Press, pp. 181-206.

Malerba, F., Orsenigo, L., 1996. Schumpeterian patterns of innovation are technologyspecific. Res. Policy 25 (3), 451-478.

Mairesse, J., \& Mohnen, P. (2010). Using innovation surveys for econometric analysis. In Handbook of the economics of innovation (Vol. 2, pp. 1129-1155). North-Holland.

Mairesse, J., Robin, S, 2012. The importance of product and process innovation for productivity in French manufacturing and services industries. In: Andersson, M., Johansson,, B., Karlsson, C, Löö, H. (Eds.), Innovation and Growth - From R\&D Strategies of Innovating Firms to Economy-Wide Technological Change. Oxford University Press.

McAfee, A., Brynjolfsson, E., 2017. Machine, Platform, Crowd: Harnessing our Digital Future. WW Norton \& Company.

Mohnen, P., Polder, M., van Leeuwen, G., 2018. ICT, R\&D and Organizational Innovation: Exploring Complementarities in Investment and Production. National Bureau of Economic Research. Working paper no. w25044.

Nambisan, S., Lyytinen, K., Majchrzak, A., Song, M., 2017. Digital innovation management: reinventing innovation management research in a digital world. MIS Q. 41 (1), 223-238.

Niebel, T., Rasel, F., Viete, S., 2019. BIG data-BIG gains? Understanding the link between big data analytics and innovation. Econ. Innov. New Technol. 28 (3), 296-316.

OECD, 2005. Oslo Manual: Guidelines for Collecting and Interpreting Innovation Data, 3rd ed. OECD Publishing.

Ouimet, P., Zarutskie, R., 2014. Who works for startups? The relation between firm age, employee age, and growth. J. Financ. Econ. 112 (3), 386-407.

Pan, M.-J., Jang, W.-Y., 2008. Determinants of the adoption of enterprise resource planning within the technology-organization-environment framework: Taiwan's communications industry. J. Comput. Inf. Syst. 48 (3), 94-102.

Parisi, M., Schiantarelli, F., Sembenelli, A., 2006. Productivity, innovation and R\&D: Micro evidence for Italy. Eur. Econ. Rev. 50 (8), 2037-2061.

Papke, L.E., Wooldridge, J.M., 1996. Econometric methods for fractional response variables with an application to 401 (k) plan participation rates. J. Appl. Econ. 11 (6), 619-632.
Pfeifer, C., Wagner, J., 2014. Is innovative firm behavior correlated with age and gender composition of the workforce? Evidence from a new type of data for German enterprises. J. Labour Mark. Res. 47 (3), 223-231.

Porter, M.E., Heppelmann, J.E., 2015. How smart, connected products are transforming companies. Harv. Bus. Rev. 93, 96-114.

Quinn, J.B., Baruch, J.J., Zien, K.A., 1996. Software-based innovation. McKinsey Q. 4, 94.

Raman, K., Wagner, A., 2011. The evolvability of programmable hardware. J. R. Soc. Interface 8 (55), 269-281.

Ruparelia, N.B., 2010. Software development lifecycle models. ACM SIGSOFT Softw. Eng. Notes 35 (3), 8-13.

Schubert, T., Andersson, M., 2015. Old is gold? The effects of employee age on innovation and the moderating effects of employment turnover. Econ. Innov. New Technol. 24 (1-2), 95-113.

Schumpeter, J. A. (1942). Capitalism, socialism and democracy. London.

Schumpeter, J.A., 1934. The Theory of Economic Development. Harvard University Press, Cambridge, MA.

Schwab, K., 2017. The Fourth Industrial Revolution. Crown Business.

Sedgwick D (2015) A new breed of software engineer. Automotive News. Available at: http://www.autonews.com/article/20150803/OEM10/308039979/a-new-breed-o f-software-engineer.

Spiezia, V., 2011. Are ICT users more innovative? OECD J. Econ. Stud. 2011 (1), 1-21.

Svahn, F., Mathiassen, L., Lindgren, R., 2017. Embracing digital innovation in incumbent firms: how Volvo cars managed competing concerns. MIS Q. 41 (1).

van de Weerd, I., Brinkkemper, S., Nieuwenhuis, R., Versendaal, J., Bijlsma, L., 2006. Towards a reference framework for software product management. In: Proceedings of the 14th IEEE International Requirements Engineering Conference (RE'06), pp. 319-322.

Veugelers, R., 1997. Internal R \& D expenditures and external technology sourcing. Res. Policy 26 (3), 303-315.

Voget, S., 2003. Future trends in software architectures for automotive systems. Advanced Microsystems for Automotive Applications 2003. Springer, Berlin, Heidelberg, pp. 457-469.

Wooldridge, J.M., 2002. Inverse probability weighted M-estimators for sample selection, attrition, and stratification. Portuguese Econ. J. 1 (2), 117-139.

Yoo, Y., Henfridsson, O., Lyytinen, K., 2010. Research commentary-the new organizing logic of digital innovation: an agenda for information systems research. Inf. Syst. Res. 21 (4), 724-735.

Martin Andersson is professor of Industrial Economics at the Blekinge Institute of Technology in Karlskrona Sweden and professor of Innovation Studies at Lund University. He also works at the Swedish Entrepreneurship Forum in Stockholm and is affiliated to the Research Institute of Industrial Economics, Stockholm. He has a PhD in economics from Jönköping International Business School (JIBS) and his research focuses on the interplay between innovation, entrepreneurship and industrial dynamics as well as on cities, agglomeration and local labor markets. He is chairman of the prize committee of the Global Award for Entrepreneurship Research and editor of Annals of Regional Science.

Anna Kusetogullari is a $\mathrm{PhD}$ candidate at the Department of Industrial Economics, Blekinge Institute of Technology. Her dissertation focused on the interplay between the use and development of digital technologies and the performance of firms, such as prospects for scaling-up, productivity and innovation. She is broadly interested in entrepreneurship research and digital transformation.

Joakim Wernberg is research leader at the Swedish Entrepreneurship Forum, focusing on the economic impact of and interaction between global macro trends. He is also affiliated to CIRCLE at Lund University as well as Lund University Internet Institute. His primary research interest are digitalization, technological change, complex adaptive systems and dynamics of labor markets. Joakim has a background in Engineering Physics and $\mathrm{PhD}$ in Economic Geography from Lund University. 